University of Chicago Law School

Chicago Unbound

Journal Articles

Faculty Scholarship

1993

\title{
When Cities Go Broke: A Conceptual Introduction to Municipal Bankruptcy
}

Randal C. Picker

Michael W. McConnell

Follow this and additional works at: https://chicagounbound.uchicago.edu/journal_articles

Part of the Law Commons

\section{Recommended Citation}

Randal C. Picker \& Michael W. McConnell, "When Cities Go Broke: A Conceptual Introduction to Municipal Bankruptcy," 60 University of Chicago Law Review 425 (1993).

This Article is brought to you for free and open access by the Faculty Scholarship at Chicago Unbound. It has been accepted for inclusion in Journal Articles by an authorized administrator of Chicago Unbound. For more information, please contact unbound@law.uchicago.edu. 


\title{
When Cities Go Broke: A Conceptual Introduction to Municipal Bankruptcy
}

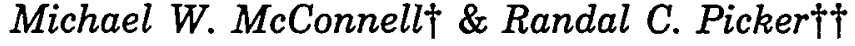

What has happened when a city goes bankrupt? Is the "municipal corporation" dissolved? What stands in its place? Do the creditors take over City Hall and the city's streets and alleys? Can the creditors obtain a lien on the city's primary source of income: taxes? Can the bankruptcy court override the decisions of elected officials regarding taxation and spending? How high must taxes go, how low must services get, and who decides? Who are the residual stakeholders? Can we pierce the municipal "corporate veil?" If we do, who is behind it? What is the role of the state?

As these questions suggest, the bankruptcy of a municipal corporation raises fundamental issues regarding the nature of the city, and a study of municipal bankruptcy promises to shed considerable light on the scholarly debate over its legal status. Yet the subject of municipal bankruptcy has received little attention in the legal literature. ${ }^{1}$ The subject is apparently of too little practical financial importance to attract the attention of bankruptcy scholars (there are, after all, few municipal bankruptcies), but of such daunting technical complexity that it has discouraged serious investigation by local government specialists. ${ }^{2}$ It is our intention to

$\dagger$ William B. Graham Professor of Law, University of Chicago Law School.

it Professor of Law, University of Chicago Law School. We thank Douglas Baird, Walter Blum, Richard Epstein, Jo Desha Lucas, Geoff Miller, Mark Ramseyer, and Alan Smith for comments.

1 For discussion of the current law, see David L. Dubrow, Chapter 9 of the Bankrutpcy Code: A Viable Option for Municipalities in Fiscal Crisis?, 24 Urban Law 539 (1992); Richard L. Epling, Fine Tuning Chapter 9 Municipal Debt Adjustments, 21 Ariz St L J 403 (1989). For discussion of the 1978 Bankruptcy Code's predecessor, see Lawrence P. King, Muncipal Insolvency: The New Chapter IX of the Bankruptcy Act, 1976 Duke L J 1157.

2 For example, Amdursky and Gillette say nothing about municipal bankruptcy in their recent treatise on the law of municipal debt finance. See Robert S. Amdursky and Clayton P. Gillette, Municipal Debt Finance Law: Theory and Practice (Little, Brown, 1992). Moreover, with one exception, the leading casebooks on local government law fail to address the issue. See Gerald E. Frug, Local Government Law (West, 1988); Daniel R. Mandelker, et al, State and Local Government in a Federal System (Michie Co., 3d ed 1990); William D. Valente and David J. McCarthy, Jr., Local Government Law: Cases and Materials (West, 4th ed 1992). The exception is Jefferson B. Fordham, Local Government Law: Legal and Related Materials 656-85 (Foundation, 2d rev ed 1986). 
bridge these two fields of legal scholarship by exploring the meaning of bankruptcy in the context of municipal corporations and what this has to say about the legal structure of cities and their relation to their citizens, their states, their creditors, and the courts.

The perennial problem of bankruptcy is twofold. At the front end, cities and other borrowers need to be able to make credible, legally-enforceable promises to repay-or no one would be willing to lend to them. This requires a legal regime strong enough to overcome the "moral hazard" problem-the tendency of debtors to prefer to devote their resources to their own interests instead of repaying their debts. At the back end, it is not always possible to pay, and it is in the interest of all (creditors as well as debtors) to reach an accommodation when this eventuality occurs. This may require coercion of unwilling parties, since individual creditors may find it in their interest to resist a solution even when it is in the interest of the creditors as a whole. This is the "collective action" problem. The rub is that bankruptcy-the solution to the collective action problem-ineluctably weakens the legal backing for promises to pay, and thus exacerbates the moral hazard problem.

In part, this Article analyzes the ways in which the legal status of municipal corporations affects these aspects of bankruptcy law. In Section I, we address the legal remedies available to municipal creditors as they existed before there was a municipal bankruptcy law. These remedies reveal both the fundamental preconceptions of the system and the purposes of the federal bankruptcy law. In Section II, we analyze the federal bankruptcy law itself, with particular attention to the ways in which it seeks to reduce the moral hazard problem. This Section concludes that municipal bankruptcy law does not well serve its intended purposes. One "solution" to the moral hazard problem is to erect barriers to municipal bankruptcy filings, which we have surely done, and to carry over into bankruptcy the key rights that creditors would have relied on outside of bankruptcy, as we may have done. Whether this is the best response to the moral hazard problem is a question to which we return below, but its effect on municipal bankruptcy has been direct-cities seldom file.

Moreover, bankruptcy law accomplishes more than merely to adjust the debts of entities unable to pay. In the private context, bankruptcy law also serves as a mechanism for reorganization so as to maximize value and minimize the recurrence of financial difficulties. It is the rare corporation that emerges from bankruptcy unchanged, its operations intact and going on as before. Federal 
municipal bankruptcy law, by contrast, is designed to perform the debt adjustment function without serving the reorganization function. Indeed, the premise of municipal bankruptcy law is that the city will emerge from bankruptcy in the same form-with the same boundaries, resources, functions, and governing structure-with which it entered bankruptcy. In Section III, we question this premise and speculate about whether bankruptcy could function in the municipal context as it does in the private context: as an instrument for more efficient organization.

Throughout the Article, we explore the ramifications of two different ways of conceptualizing a city: as a political subdivision of the sovereign state, and as the agent of the private citizens who inhabit it. These conceptions of the city influence both the range of creditors' rights and the features of the federal bankruptcy law. But they are of particular importance to the final Section. The former view of the city, as an arm of the state, suggests that municipal bankruptcy should be treated as an occasion for consolidating the distressed municipality into larger units of government, or for larger units (probably the state) to bear some responsibility for the debts of the city. The latter view, that the city is the agent of its private citizens, suggests that bankruptcy should allow the dissolution of the municipal corporation into its constituent parts, followed by voluntary reorganization into more efficient and effective units. Under either view, we suggest that bankruptcy law could serve more ambitious purposes than mere debt adjustment if we ceased to hold the present configuration of cities as sacrosanct.

\section{Municipal Debt Enforcement and Adjustment Before Passage of the Federal Act}

Prior to 1933 , there was neither state nor federal municipal bankruptcy legislation. Indeed, it appeared, for a time, that the Constitution prevented either level of government from touching the subject. For the federal government to do so would intrude into the internal governance of states and their political subdivisions and thus violate state sovereignty; ${ }^{3}$ for the state government to do so would impair the obligation of contracts (something the federal government may do but states may not). ${ }^{4}$ Congress did not

3 Ashton v Cameron County District, 298 US 513, 531 (1936).

- See Hanover Nat'l Bank v Moyses, 186 US 181, 188 (1902) (“[Congress's power under the Bankruptcy Clause] includes the power to discharge the debtor from his contracts and legal liabilities, as well as to distribute his property. The grant to Congress involves the power to impair the obligations of contracts, and this the States were forbidden to do."); 
venture to pass a municipal bankruptcy law until the Great Depression, and the Supreme Court's first reaction was to strike it down. ${ }^{5}$ By 1942, however, the Supreme Court would saw off both horns of this doctrinal dilemma. In 1938, in United States $v B e-$ $k i n s,{ }^{6}$ the Court upheld Congress's second attempt to pass a municipal bankruptcy statute, and in 1942, in Faitoute Iron \& Steel Co. $v$ Asbury Park, ${ }^{7}$ it upheld the states' authority to compel unwilling creditors to join in a plan of adjustment of municipal debts. But until that time--and when Congress was drafting the original municipal bankruptcy statute-the very possibility of municipal debt relief raised grave constitutional doubts. Thus, the fundamental premises of current law were shaped by pre-1938 constitutional considerations: the Contracts Clause explains why we have a federal bankruptcy statute for municipalities (instead of leaving the matter to state law), while the principle of state autonomy explains its narrow scope (in contrast to private bankruptcy law).

The 1937 Act was originally adopted as a temporary emergency measure, and was to expire in 1940. It was extended several times $^{8}$ and was made permanent in $1946 .{ }^{\circ}$ Congress revised the Act substantially in $1976,{ }^{10}$ made additional changes as part of the enactment of the 1978 Code, and further tinkered with the statute in $1984^{11}$ and $1988 .{ }^{12}$ We will discuss the provisions of current law in detail in Section II. We begin, however, with a discussion of the law of municipal default before 1933, for two reasons. First, the bankruptcy regime has meaning only as compared to the state of affairs that exists outside of bankruptcy. Second, many of the most interesting features of modern municipal bankruptcy have their origins not in the federal acts, but in the law that preceded them. To a surprising degree, the shape of modern litigation over municipal insolvency was set by the (in some ways artificial) legal categories of the mid- to late nineteenth century.

Michael W. McConnell, Contract Rights and Property Rights: A Case Study in the Relationship Between Individual Liberties and Constitutional Structure, 76 Cal L Rev 267 (1988) (discussing reasons why the Contracts Clause applies only to the states).

${ }^{5}$ Ashton, 298 US 513.

6 304 US 27 (1938).

7316 US 502 (1942).

${ }^{8}$ See, for example, Act of June 28, 1940, 54 Stat 667, 670 c 438 (1940) (extending the Act until 1942).

- 60 Stat 409 , codified at 11 USC $\$ \$ 401$ et seq (1946).

${ }^{10}$ Pub L 94-260, 90 Stat 315, codified at 11 USC $\$ \S 401$ et seq (1976).

11 Bankruptcy Amendments and Federal Judgeship Act of 1984, PL 98-353, 98 Stat $333,383-84$, codified at 11 USC $\$ \$ 490-98$ (1984).

${ }_{12}$ Municipal Bankruptcy Amendments, Pub L 100-597, 102 Stat 3028 (1988). 
In the absence of federal statutory law, the question of municipal default was governed by state statute and state and federal common law. ${ }^{13}$ During this period, the law of municipal bankruptcy was the law of creditors' remedies. Cities could not declare bankruptcy, but they could-and frequently did-fail to pay their debts. Thus, the legal question was: what could the courts do to compel cities to meet their financial obligations? Among the remedies creditors of a municipality might seek were: (1) seizure of city property; (2) judicial oversight of city financial affairs, including limitations on expenditures that would divert funds away from debt service; (3) seizure of private property within the city; (4) state assumption of municipal indebtedness; (5) obtaining a lien on future tax revenues; and (6) imposition of new taxes earmarked for debt service.

Each of these theoretical remedies, except the last, has an analogue in private bankruptcy. Seizure of assets is the quintessential creditor's remedy - the right to levy on assets is the ultimate backing of private debt. Judicial supervision of financial affairs closely tracks the current role of the Bankruptcy Court under the Code. A central feature of these remedial regimes is the court's power to ensure that the debtor does not make unnecessary or unreasonable expenditures that reduce its ability to pay its debts. Seizing private property is analogous to piercing the corporate veil; this forces the real owners of the corporation to assume its obligations. Requiring the state to assume municipal obligations is analogous to requiring a parent corporation to assume the debts of its subsidiary. A lien on future taxes is similar to garnishing wages or obtaining a lien on future income. Only the remedy of new taxes lacks a close private analogue. A private creditor may be able to garnish the wages of a debtor or obtain a lien on the debtor's future income stream, but he cannot force the debtor to go out and make more money. Interestingly, although municipal creditors attempted each of these avenues for relief, only the last avenue was usually available in actual practice.

\section{A. Seizure of City Property}

The most basic remedy available to creditors in the private sphere is seizure of the debtor's property. If this remedy were

13 These were the days before Erie Railroad Co. $v$ Tompkins, 304 US 64 (1938), which was decided in the same year that the second municipal bankruptcy act was upheld by the Supreme Court. 
available to municipal creditors, they could seize the assets of the city (city hall, schools, police equipment, fire trucks, streets and alleys, and so forth) in satisfaction of the debt. This remedy understands the city to be a mere corporation, established by its citizens for particular purposes, more akin to a business corporation than to a sovereign government.

Strange as it may seem, it was not unusual to view municipal corporations as quasi-private organizations serving the interests of their members rather than as inherently political entities. In a classic mid-nineteenth century case, the Ohio Supreme Court explained the denial of sovereign immunity for a city's torts on the ground that "municipal corporations proper" are "created mainly for the interest, advantage, and convenience of the locality and its people" rather than being part of the "sovereign and paramount authority" of the State. ${ }^{14}$ More pointedly, in Kaufman $v$ City of Tallahassee, ${ }^{15}$ the Supreme Court of Florida commented that "a city's functions have become more and more ministerial, in that its duties consist largely, if not entirely, in the management of public utilities such as waterworks and sewerage systems, electric lighting and power plants, gas plants, telephones, and street railways, ... for the financial advantage and profit of the city."16 According to the court it took "very little stretching of this doctrine" to say that "no municipal function is governmental, a city is not a political subdivision of the state, not a government but purely a business, commercial, proprietary management of local public interests."17 This was an extreme statement of a common view of cities during that era-one which lends credence to the claim of creditors to municipal property in the event of default. Why not, if cities are essentially business enterprises? ${ }^{18}$

Notwithstanding inflated rhetoric about the similarity of cities to businesses, no court permitted such a drastic remedy. Some courts flatly held that no property of a municipal corporation may be seized by the creditors. ${ }^{19}$ The predominant rule, however, was that only property held in a proprietary capacity was subject to

${ }^{14}$ Comm'rs of Hamilton Co. $v$ Mighels, 7 Ohio St 109, 119 (1857). See also City of Trenton v New Jersey, 262 US 182, 191-92 (1923), and cases cited therein.

1s 84 Fla 634, 94 S 697 (1922).

16 Id at 699 .

17 Id.

${ }^{18}$ For a modern expression of this view, see Robert C. Ellickson, Cities and Homeowners Associations, $130 \mathrm{U} \mathrm{Pa}$ L Rev 1519 (1982) (comparing cities to homeowners' associations).

19 See, for example, City of Chicago v Hasley, 25 Ill 595 (1861). 
debt foreclosure. "Public property" dedicated to a "public use"-such as "streets, wharves, cemeteries, hospitals, courthouses, and other public buildings"20 _ was exempt, as were funds held in the municipal treasury for general use. ${ }^{21}$ The doctrinal explanation was that this property was held in "trust for the public" and "to no other use can [it] be appropriated without special legislative sanction."22 This doctrine was based on the legal fiction that municipal property was owned by the public but the debts were owed by the corporation. As the Louisiana Supreme Court explained in a leading case:

an execution can not be levied on any property held by a municipality or other public corporation for public purposes, ... the principle being that title to such property is held in trust for the public and hence can no more be sold to settle the debts of a city or other political subdivision than can any other trust property be sold to settle the individual debts of any other trustee. ${ }^{23}$

This was a strange way of looking at the matter, for it treated the city government as identical to the public for purposes of property ownership but as a private interest for purposes of payment of municipal debts. Perhaps the point was that the city held the property in trust not for its citizens but for the general public. In this view, the issue was not whether trustees were taking from the beneficial owner of the trust, but whether one public (citizens of the city) was taking from another public (the people of the state or nation). This is consistent with the "public trust" doctrine, which holds (among other things) that municipalities may not favor residents over nonresidents with respect to the use of certain lands held in trust for the people. ${ }^{24}$ But the doctrine applies only to property open to the general public, such as streets, parks, and waterfront. More convincing with reference to most property was the straightforward concern of other courts that a seizure of municipal property could prevent the city from performing its essential gov-

${ }^{20}$ Meriwether v Garrett, 102 US 472, 513 (1880).

${ }^{21}$ Droz v Parish of East Baton Rouge, 36 La Ann 340 (1884).

${ }_{22}$ Meriwether, 102 US at 513.

2s Town of Farmerville v Commercial Credit Co., $173 \mathrm{La} 43,136 \mathrm{~S} 82,85$ (1931), quoting $17 \mathrm{RCL} \S 43$ at 145 (emphasis in original).

${ }^{24}$ See, for example, Matthews v Bay Head Improvement Ass'n, 95 NJ 306, 471 A2d 355,358 (1984). On similar logic, it was thought that city officials had no authority to sell common lands. 
ernmental functions-an unthinkable result." "However strong the obligation of a town or city to pay its debts," an Illinois appellate court stated, "to allow payment to be enforced by execution would so far impair the usefulness and power of the corporation, in the discharge of its government functions, that the public good required the denial of such a right."28

In theory, this principle did not apply to all municipal property; there was a class of property "which is not and can never be needed for strictly municipal or public purposes," and was therefore available to creditors. ${ }^{27}$ The Supreme Court described as "proprietary" property "held in [the municipality's] own right for profit or as a source of revenue, not charged with any public trust or use." ${ }^{28}$ This might include, for example, an unused vacant lot outside the corporate limits ${ }^{29}$ or a private residence taken for failure to pay taxes. ${ }^{30}$ Some courts suggested it might extend to property used to provide services that could just as well be provided by private firms, such as water or gas $^{31}$ (though when push came to shove this was usually rejected ${ }^{32}$.

The dichotomy between the governmental and proprietary functions of municipalities was closely related to a wider legal conception of cities, which in their governmental capacities were seen (in the mid- to late nineteenth century) as wholly subordinate to the state, but in their proprietary capacity as independent of state power and control. ${ }^{33}$ For example, courts sometimes held that the

${ }^{25}$ Addyston Pipe \& Steel Co. $v$ City of Chicago, $170 \mathrm{mll}$ 580, 48 NE 967, 968 (1897), overruled by Henderson v Foster, $59 \mathrm{Mll}$ 2d 343, 319 NE2d 789 (1974). See also Hasley, $25 \mathrm{IIl}$ at 596.

${ }^{28}$ Brazil $v$ City of Chicago, 315 Ill App 436, 43 NE2d 212, 214 (1942). This remains the general rule today. For example, in a much-noted decision, a lower state court allowied a judgment creditor to seize the City Hall of East St. Louis, but the decision was overturned on appeal. See Estate of DeBow v City of East St. Louis, $228 \mathrm{Ill}$ App 3d 437, 592 NE2d 1139 (1992), appeal granted, 146 Ill 2d 626, 602 NE2d 450 (1992).

${ }^{27}$ Farmeruille, $136 \mathrm{~S}$ at 85.

${ }^{28}$ Meriwether, 102 US at 518.

${ }^{29}$ Murphree $v$ City of Mobile, 108 Ala 663, 18 S 740, 741 (1895). For a recent example, see Estate of DeBow, $592 \mathrm{NE2d}$ at 1144-45 (upholding seizure of a 220-acre tract of vacant land, a former industrial site, on the ground that the record was devoid of any evidence that the tract "serves any cognizable municipal function").

${ }^{30}$ City of Sherman $v$ Williams, 84 Tex 421, 19 SW 606, 606-07 (1892).

31 Flutmus $v$ City of Newport, $175 \mathrm{Ky} \mathrm{817,194 \textrm {SW }} 1039$ (1917) (waterworks). See also Darling \& Morse v Mayor and City Council of Baltimore, 51 Md 1, 12-13 (1878) (discussing and ultimately rejecting the distinction).

${ }^{32}$ See Bullis v Town of Jackson, 4 S2d 550, 552 (La App 1941); 76 ALR 695, 695-700 (1932).

${ }^{33}$ See John Dillon, Treatise on the Law of Municipal Corporations, ch 1, \& 9 at 82-83 \& $n 1$ (J. Cockcroft, 1st ed 1872) (explaining and criticizing the distinction). 
state could expropriate municipal property without compensation if the property was governmental, but was obliged to pay compensation under the Fifth Amendment or corresponding provisions of state constitutional law for the taking of municipal property held in a proprietary capacity. ${ }^{34}$ Municipal corporations were chimerical institutions-half sovereign (hence subdivisions of the state), half corporation (hence creations of their incorporators, with property rights against the state).$^{38}$ Insofar as cities were corporations, creditors could seize their assets in satisfaction for debts; but insofar as they were governments, the property belonged to the people of the state and could not be diverted to private purposes-even to the purposes of paying the lawful debts of the muncipal corporation incurred on behalf of the people.

In actual practice, very little property fell into the "proprietary" category. Even when courts recognized creditors' rights to execute against the quasi-private property of the municipality in theory, they strained to vitiate the protection. Rental payments by an entertainment company for use of a public opera hall were said to be on account of a public use because the space might be needed for public offices in the future..$^{36}$ One court even called the leasing of vacant realty a public use because the property was being held for more advantageous future sale..$^{37}$ The scope of "public use" was, in reality, as broad as the legitimate activities of the city. According to the leading commentator of the era, " $t]$ he instances in which anything is collected by levy upon a municipality's property, or upon some alleged proprietary fund, are few."ss

This meant that the principal backstop of private creditors' rights-the right to seize the assets of the debtor-was unavailable to the municipal creditor. Understanding the merits-or demer-

\footnotetext{
34 James Kent, 2 Commentaries on American Law 275 (Halsted, 3d ed 1836). See Town of Milwaukee v City of Milwaukee, 12 Wis 93, 109 (1860); Grogan v San Francisco, 18 Cal 590, 612-13 (1861); Mount Hope Cemetery v Boston, 158 Mass 509, $33 \mathrm{NE} 695,698$ (1893); Spaulding $v$ Andover, 54 NH 38, 56 (1873); Hunter v City of Pittsburgh, 207 US 161, 179-80 (1907) (dictum). The Supreme Court repudiated this argument as a matter of federal constitutional law in City of Trenton v New Jersey, 262 US 182, 191-92 (1923).

ss See Gerald E. Frug, The City As A Legal Concept, 93 Harv L Rev 1057, 1099-1109 (1980). For a typical statement of the position in a judicial opinion, see City of Hazard $v$ Duff, 287 Ky 427, 154 SW2d 28, 29 (1941).

3s Board of Councilmen of City of Frankfort $v$ White, $224 \mathrm{Ky} \mathrm{570,6}$ SW2d 699, 701-02 (1928).

${ }^{37}$ United Taxpayers Co. $v$ City and County of San Francisco, 202 Cal 264, 259 P 1101, 1102 (1927).

${ }^{38}$ A.M. Hillhouse, Municipal Bonds: A Century of Experience 277 (Prentice-Hall, 1936). But see $D u f f, 154 \mathrm{SW} 2 \mathrm{~d} 28$ (allowing execution against a building owned by municipal waterworks).
} 
its-of this is complex. One of the most damning criticisms of debtor-creditor law in the private sector is that individual creditors will seize property of the failing debtor without regard to the collective interest of the creditors. ${ }^{39}$ Value that might well be available to the creditors as a group will be dissipated as individual creditors descend on the failing debtor and pick over its assets. A particular creditor has no reason to consider how its actions affect others. There may be ways to eliminate this problem through the careful grant of security interests, ${ }^{40}$ but the municipal seizure rule addresses the problem directly and largely eliminates it, possibly making it a better rule. ${ }^{41}$

The critical question is whether anything is lost by denying creditors the right to seize assets. Seizure of assets attracts attention to the debtor and may precipitate a bankruptcy filing, either by the debtor or by the creditors. Such a filing may be in the interest of the creditor group, since bankruptcy is the collective proceeding for debt collection and since bankruptcy results in-at least in the private context-more oversight over the debtor's affairs. A bankruptcy filing may limit the extent to which the debtor can dissipate assets. The issue then is a trade-off: seizure itself may dissipate value but may reduce the extent to which the debtor otherwise dissipates value. It is quite possible that an intermediate procedure might be best. If creditors were barred from seizing assets but were able to achieve priority over those assets through public filings, we would avoid the direct seizure loss but might still retain enough of the public character of seizure to ensure that attention is drawn to the debtor's situation. ${ }^{42}$

\section{B. Judicial Oversight of City Financial Affairs}

For nonmunicipal debtors, filing for bankruptcy results in a substantial relinquishment of control over their day-to-day affairs. The loss is almost total when a trustee is appointed, but even when the debtor acts as debtor-in-possession, the loss of control is palpable. Decisions out of the ordinary course of business require court

\footnotetext{
39 See, for example, Thomas H. Jackson, The Logic and Limits of Bankruptcy Law 10 (Harvard, 1986).

${ }^{40}$ See Randal C. Picker, Security Interests, Misbehavior, and Common Pools, 59 U Chi L Rev 645 (1992).

42 We also note that there may be losses from moving assets from public to private hands; this is a general concern which we develop more extensively later in the Article.

42 A few states have moved in the direction of allowing priority through filing without seizure as to the property of private debtors. See William J. Woodward, Jr., New Judgment Liens on Personal Property: Does "Efficient" Mean "Better"?, 27 Harv J Leg 1, 4 (1990).
} 
hearings with all parties in interest having an opportunity to be heard. ${ }^{43}$ Expenditures of the debtor are closely scrutinized to ensure that any available surplus will be devoted to creditors' claims.

By contrast, the courts had no authority to limit the discretion of city officials to control the operating budget of the municipality. In East St. Louis v Zebley, the Supreme Court held that "the question, what expenditures are proper and necessary for the municipal administration, is not judicial; it is confided by law to the discretion of the municipal authorities. No court has the right to control that discretion." 44 The theory seems to be that the level of expenditures is an inherently political issue, not susceptible to scientific and disinterested evaluation. It would violate structural principles of federalism and separation of powers for federal courts to interfere with local democratic decisionmaking about levels of spending. In effect, this gave current city expenditures absolute priority over payment of past obligations.

This feature of the common law is now codified in the Bankruptcy Code. ${ }^{45}$ The resulting freedom of the municipal debtor to spend at will on objects of its own choosing, notwithstanding the effect on the creditors, is one of the most significant differences between private and municipal bankruptcy. Priorities in bankruptcy are not unusual- $\$ 507$ contains a lengthy list of priorities and $\S 1114$ creates a complex priority for retiree benefits. Nonetheless, "the public good" has no natural definition, ${ }^{46}$ and we would expect an expansive interpretation of it by city officials faced with a choice between paying bondholders and providing benefits to constituents. The particular quality of this priority places municipal creditors in a position unlike that of any private creditor. It removes one of the principal disincentives to fiscal irresponsibility, exacerbating the moral hazard problem of bankruptcy.

This judicial reticence to invade local political authority extended even to more ministerial functions, such as the collection of

13 See 11 USC \& 363(b) (1988).

4110 US 321,324 (1884). For a striking example, in which a creditor was unable to obtain enforcement of a $\$ 300$ debt owed by the city, see Bullis, 4 S2d at 553:

It may be that some of the items budgeted by the defendant town as expenditures appear to be a bit high, but there is certainly no proof to show that they are inflated or were arbitrarily fixed with the ideas of padding the budget to escape the payment of any legitimate debts due by it. Besides, the framing of their budgets seems to be a matter which is left to the discretion of the town councils, and courts are without authority to regulate them in preparing or supplementing the same.

${ }^{45}$ See text accompanying notes $160-68$.

16 See City of Columbia v Omni Outdoor Advertising, Inc., 111 S Ct 1344, 1352 (1991). 
taxes already imposed. In some notorious cases, city officials deliberately frustrated enforcement of taxes levied to secure payment of municipal debts, in some instances resigning so that there was no one to carry out the legal duty of tax collection. In the absence of express statutory authorization by the state, courts held that they could not appoint a receiver to perform these functions. ${ }^{47}$

A few states, however, imposed oversight boards or receiverships in cases of municipal default. The first such system was instituted by Missouri in the mid-1870s. This system gave creditors the option of accepting compromise bonds, which, if unpaid, would be redeemed through appointment of an official to assess and collect taxes sufficient to pay all judgments. ${ }^{48}$ Similarly, Texas legislation required the governor to appoint a tax collector in the event that the elected collector should resign or refuse to collect the taxes required for repayment of interest and principal. ${ }^{49}$ The State of Tennessee imposed the first formal municipal receivership on Memphis, in the notorious municipal default that led to the famous. Supreme Court case of Meriwether $v$ Garrett. ${ }^{00}$ The state legislature literally disincorporated Memphis in 1879, transferring its territory and municipal functions to an entity called the "Taxing District of Shelby County," and the governor appointed commissioners to put the financial affairs of the city into order. ${ }^{51}$ Other cities placed in receivership under state law included Mobile, Alabama; Manchester, New Hampshire; and Fall River, Massachusetts. During the Depression, a wave of piecemeal state legislation permitted or required receiverships in the event of municipal defaults-though only New Jersey and Massachusetts had comprehensive legislation of this type. ${ }^{52}$ As discussed in more detail below, ${ }^{58}$ receiverships under state law continue to play a major role in resolving municipal financial crises.

For the most part, state receivership laws were special legislation enacted, like the first federal municipal bankruptcy statute, during the Great Depression. In the pre-Act period, receiverships were rarely available, and never at common law. Federal courts thus lacked authority to oversee municipal finances.

4 See, for example, Walkley $v$ City of Muscatine, 73 US 481 (1867).

48 Hillhouse, Municipal Bonds at 323-24 (cited in note 38).

4 Id at 324.

so 102 US 472 (1880).

s1 Id at $477-95$.

62 The New Jersey scheme is described in Hourigan $v$ North Bergen Township, 113 NJL 143, 172 A 193, 194-97 (1934).

ss See text accompanying notes 203-11. 


\section{Seizure of Private Property Within the City}

Some creditors sought to levy execution on the property of private persons within the defaulting jurisdiction. The theory was that the city is a creation of its citizens for their mutual benefit, and that the citizens are therefore the residual stakeholders, both as to assets and as to obligations. The relation of the citizen to the city was thus analogized to that of the shareholder to the corporation without limited liability; in effect, when you pierce the municipal corporate veil, you find the citizens of the municipality. Another analogue might be the partnership, where general partners are personally liable for the debts of the partnership.

The notion that a private person's property could be seized to pay the debt of the city now seems unthinkable, but it was (and still is, in theory at least) the rule in most of the New England states. Interestingly, the courts in these states did not appeal to the private corporation analogy, but instead treated the municipal corporation as "by immemorial usage an exception" from the general rule that "an individual member of an aggregate corporation is not liable for any debts or demands against it."54 The Connecticut Supreme Court reasoned that municipal or quasi-corporations are "not, strictly speaking, corporations, but only municipal bodies, without pecuniary funds," and thus are not entitled to the protection of limited liability. ${ }^{\circ 5}$ The Supreme Judicial Court of Massachusetts observed that "[t]owns, parishes, precincts, \&c., are but a collection of individuals with certain corporate powers for political and civil purposes, without any corporate fund from which a judgment can be satisfied, but each member of the community is liable in his person or estate to the execution which may issue against the body." ${ }^{\prime 36}$ A similar approach was adopted by statute in New Hampshire, Vermont, and Maine. ${ }^{57}$

Outside of New England, the enforcement of municipal debts against private citizens was uniformly rejected. ${ }^{58}$ Summarizing

s4 Chase v Merrimack Bank, 36 Mass 564, 568 (1837). The absence of a "corporate fund" created the ground of distinction.

s5 Beardsley $v$ Smith, 16 Conn 368, 376 (1844).

bs Merchants Bank v Cook, 21 Mass 405, 414 (1826); Chase, 36 Mass at 569.

${ }^{57}$ Hillhouse, Municipal Bonds at 277 (cited in note 38). See also John F. Dillon, 4 Commentaries on the Law of Municipal Corporations § 1506 at 2673-74 n 4 (Little, Brown, 5th ed 1911).

ss A partial exception was the Commonwealth of Kentucky, which passed special acts in the 1870s that induced creditors to accept compromise bonds and gave them the right to levy upon the private property of inhabitants if these new obligations were not satisfied. Hillhouse, Municipal Bonds at 324 (cited in note 38). Generally, the New England rule was 
state law, the United States Supreme Court held that "the private property of the inhabitants of a municipal body cannot be subjected to the payment of its debts, except by way of taxation." Justice Strong invoked the analogy to the limited liability corporation: "the private property of individuals within the territorial limits of a municipal corporation cannot be reached by its creditors directly, any more than the private property of stockholders in other corporation can thus be reached." ther, one could argue that the relation between citizen and the city is not akin to that of ownership. The only claim of the city (or its creditors) on the property of the citizen is that to which the citizen has consented through the democratic process-which means taxation with representation.

Rejection of the New England rule might also be explained on the basis of more mundane considerations of practicality. These considerations were detailed by the California Supreme Court in an opinion by Stephen Field, later Justice of the United States Supreme Court:

There appear to us insurmountable difficulties in the way of any just application of the [New England] rule. The inhabitants of a county are constantly changing; those who contributed to the debt may be non-residents upon the recovery of the judgment, or the levy of the execution; those who opposed the creation of the liability may be subjected to its payment, whilst those by whose fault the burden has been imposed may be entirely relieved of responsibility. Again it is a settled principle that whenever one of several is held liable for their joint debt, he may have recourse, upon its payment, to the others for contribution. To enforce this right against the inhabitants of a county, even where its population is small, would lead to such a multiplicity of suits as to render the right utterly valueless. ${ }^{61}$

The conflict between the New England rule and the rule that prevailed elsewhere in the country replicates the argument over the desirability of limited liability in corporation law generally. ${ }^{62}$

rejected as a matter of common law, but sometimes by state statute or city charter. For an example of the latter, see Rees $v$ City of Watertown, 86 US 107, 120-21 (1873).

s9 Meriwether, 102 US at 519.

${ }^{60}$ Id at 526 (Strong, dissenting in part on other grounds).

${ }^{61}$ Emeric $v$ Gilman, $10 \mathrm{Cal} 404,408-09$ (1858).

${ }^{62}$ See generally Tony Orhinial, ed, Limited Liability and the Corporation (Croom Helm, 1982); Frank Easterbrook and Daniel R. Fischel, Limited Liability and the Corpora- 
The central concern with limited liability is that it permits shareholders acting through the corporation to externalize risk. By definition, nonconsensual creditors-tort victims, environmental claimants and others-cannot negotiate with the shareholders to extend their recourse from the assets of the corporation to the personal assets of the shareholders. Instead, limited liability forces them to look only to the assets of the corporation. Shareholders acting through the corporation therefore bear only part of the downside risk associated with corporate actions; limited liability allows them to dump risk on outsiders. ${ }^{63}$ This is a powerful argument against limitation of liability.

Treating each part owner of a corporation as jointly and severally liable for corporate liabilities to the full extent of his property, however, is even more undesirable-which explains the extensive worldwide adoption of some form of limited liability for corporate associations. ${ }^{64}$ Such an arrangement divorces potential liability from potential gain; a billionaire owning one share of stock in Johns-Manville would put his entire fortune at risk without receiving any commensurate claim on corporate profits. This would render the public corporation an unusable form of financial organization. Even worse, each stockholder becomes the insurer not only for the risk of corporate insolvency, but for the insolvency of his fellow shareholders. If the corporation owes money in excess of its assets, a solvent shareholder will be forced to assume the liabilities of those who are insolvent. Moreover, the collection costs would be astronomical: the creditor would sue a convenient shareholder for the full amount of the debt, and the shareholder/defendant would have to bring hundreds of thousands of suits against his fellow shareholders for contribution. There are, in addition, as noted by Justice Field in the municipal context, thorny questions of timing: does liability attach to the shareholders at the time of the wrongdoing, the time of the injury, the time of the filing of the lawsuit, the time of the judgment, or some combination of the above? ${ }^{85}$ As litigation over insurance coverage of asbestos tort liability demon-

tion, 52 U Chi L Rev 89 (1985); Philip I. Blumberg, Limited Liability and Corporate Groups, 11 J Corp L 573 (1986).

6s See, for example, Henry Hansmann and Reinier Kraakman, Toward Unlimited Liability for Corporate Torts, 100 Yale L J 1879 (1991). Note that in the private context, consensual creditors can negotiate for personal guarantees, at least in the case of closed corporations. This alternative is not available in the municipal context.

* For a useful summary of the arguments, see Blumberg, $11 \mathrm{~J}$ Corp L at 611-22 (cited in note 62).

es Emeric, 10 Cal at 408-09. 
strates, ${ }^{66}$ these issues are not only unanswerable in theory, but are easily subject to manipulation as well..$^{67}$

There is an additional, perhaps subtler, defect in a regime of unlimited liability for corporations. A key feature of the public corporation is its separation of management from control, and a key purpose of unlimited liability would be to give the shareholders the incentive to monitor the activities of the managers so as to minimize losses to third parties. But one difficulty with this is that liability will attach to those who devote their best efforts to monitoring, just as it will those who are negligent or even malevolent. Without more, shareholders will face a collective action problem, making unlimited liability neither a reliable nor a fair way of improving monitoring.

It should be readily apparent that in all these respects, the question of limited liability for municipal corporations is essentially the same as that for private corporations: unlimited personal liability divorces risk from share of gain, thus discouraging otherwise desirable "membership" in the city, it makes each citizen an insurer of the risk of insolvency of his fellow citizens, it entails enormous collection costs, it poses unanswerable questions of the timing of liability with attendant effects on mobility, and it punishes the just along with the unjust. Justice Field's analysis of the issues in Emeric $v$ Gilman bears a close resemblance to the law and economics literature on limited liability today. ${ }^{88}$

6s See Richard A. Epstein, The Legal and Insurance Dynamics of Mass Tort Litigation, $13 \mathrm{~J}$ Legal Stud 475, 495-505 (1984).

ez For a more extended discussion of the procedural problems raised by dropping limited liability, see Janet Cooper Alexander, Unlimited Shareholder Liability Through a Procedural Lens, 106 Harv L Rev 387 (1992), and the response thereto, Henry Hansmann and Reinier Kraakman, A Procedural Focus on Unlimited Shareholder Liability, 106 Harv L Rev 446 (1992).

os One difference must be noted. The question of limited liability is significant in the private context principally with regard to nonconsensual creditors (such as recipients of tort judgments) because consensual creditors can bargain for additional security or guarantees. These alternatives are not generally available to municipal consensual creditors because most public property cannot be used as collateral, see text accompanying notes 14-42, and because it is unlikely that private parties would serve as guarantors for municipal debt (though the state might, and sometimes does). On the other hand, until recently municipalities were immune from most forms of tort liability. Note, Municipal Tort Liability in Operation, 54 Harv L Rev 437, 438-45 (1941). See Molitor v Kaneland Community Unit District No. 302, $18 \mathrm{Ill} 2 \mathrm{~d} \mathrm{11,163} \mathrm{NE2d} \mathrm{89,91-94} \mathrm{(1959).} \mathrm{Thus,} \mathrm{the} \mathrm{question} \mathrm{of} \mathrm{limited} \mathrm{liability} \mathrm{for}$ municipalities in the pre-Act period was principally relevant to consensual creditors in the municipal context; 
An intermediate approach between limited liability and unlimited liability is pro-rata liability. ${ }^{69}$ Shareholders would be liable for the debts of the corporation only to the extent of their proportional investment (or right to share in the profits). ${ }^{70}$ One shareholder does not serve as guarantor for another shareholder, and this elimates the concern of disproportionate exposure for solvent shareholders. It will not eliminate the collection costs associated with unlimited liability and avoided by limited liability. The collection costs are borne directly by the corporate creditor rather than by a solvent shareholder, but this is unimportant. After the fact, these collection costs simply transfer value, and if we ignore distributional concerns, this gets us nothing. The important question is whether the collection costs associated with pro-rata liability buy us enough in return. Pro-rata liability for shareholders might obviate most of the externalization of costs characteristic of limited liability. With the shareholders exposed to additional risk, they will have an incentive to monitor managers to guard against inefficient risk. ${ }^{71}$

A case can be made that the law of municipal obligation roughly approximates the proportional solution. As will be described in detail below, the principal remedy if a city fails to pay its debts is for the court to issue a writ of mandamus requiring a tax levy sufficient to pay principal and interest due. In effect, this forces citizens of the city to pay the liability in accordance with their proportionate tax liability. It solves the collection problem by using the already-existent tax system to collect the judgment and implicitly resolves the timing question by attaching liability to the citizens of the city in the fiscal year following entry of the writ. ${ }^{72}$ There is no need for the more draconian and less efficient remedy of allowing suits directly against private citizens.

Whether pro-rata liability is a good rule depends on whether citizens will be induced to monitor in order to avoid the extra taxes and whether that increase in monitoring will more than offset a

CO Yet another is some type of capped liability exposure. For a discussion of the history and merits of one form of this, double liability in banking, see Jonathan R. Macey and Geoffrey R. Miller, Double Liability of Shareholders: History and Implications, 27 Wake Forest L Rev 31 (1992).

70 See Blumberg, $11 \mathrm{~J}$ Corp L at 627-29 (cited in note 62).

11 Whether that incentive will result in monitoring depends on whether the collective action problem faced by shareholders can be overcome. Also, the likely monitoring response of creditors must be considered, as it is the net change in monitoring that matters.

' 72 It should be noted that the inability of creditors to foreclose on public property effectively eliminates the ability of secured creditors to separate themselves from the risks borne by nonsecured creditors, which further exacerbates the monitoring problem. 
decrease in monitoring by municipal creditors. These creditors will be able to avoid the substantial collection costs that they would face in the private context, and thus they should take the pro-rata remedy - in this case, the tax remedy-seriously. The relative collective action problems faced by citizens, on the one hand, and creditors, on the other, should determine this outcome. Citizens act collectively through voting. Confronted with a tax increase due to inefficient risk-taking by city managers, citizens may throw the bums out. This may be enough of a threat to compensate for the decrease in creditor monitoring. Thus, the ability to require a tax levy to pay debts, which approximates the rule of pro-rata liability, may very well be an efficient outcome.

And note where this puts the New England rule, which allowed direct seizure of citizen property. Direct democracy in New England towns mitigates collective action problems. Any doubts about whether periodic votes by citizens on the fate of officeholders suffices can be put to one side. The New England town meeting makes citizens the best group for solving the collective action problem in monitoring and makes direct liability for citizens a more sensible outcome then it would be elsewhere.

\section{State Assumption of Municipal Indebtedness}

It would have seemed in keeping with the constitutional status of municipalities for creditors to seek payment from the state upon default by the city. Cities were, after all, deemed to be mere creatures of the state, exercising a portion of the state's sovereign power for the benefit of the state and enjoying the state's immunity from federal taxation. ${ }^{73}$ It was not to be so. During the railroad debt crises of the 1860 s and 1870 s, some state constitutional conventions expressly prohibited the assumption of local debts, ${ }^{74}$ and elsewhere the remedy was denied less officially. No case held a state liable for the debts of its municipalities, and usually the argument was not even made.

This is not to say that states always left financially troubled municipalities to their own devices. States frequently took action to increase state aid to the struggling municipality and (in rare cases) sometimes even formally assumed responsibility for repayment of some portion of the debt. In 1927, Arkansas assumed the

${ }^{73}$ United States v Kagama, 118 US 375, $379-80$ (1886); United States v Baltimore \& Ohio R. Co., 84 US 322, 329 (1872).

${ }^{74}$ Hillhouse, Municipal Bonds at $323 \mathrm{n} 6$ (cited in note 38). 
debt service upon about $\$ 53$ million of local road district bonds-more than one-third of all local debts. ${ }^{75}$ Massachusetts established a revolving fund account in 1933 from which municipalities could borrow in case of short term cash flow problems. ${ }^{76}$ But it was never thought that states had a legal obligation to do these things, or that states stood behind the debts of their cities.

This practice makes the most sense when cities are envisioned as creations of their own citizens for the purpose of providing a higher level of government services than otherwise would be available. In this view, the citizens of the city-not the citizens of the state-benefit from the city's expenditures and should be responsible for them. It makes less sense when cities are envisioned as creatures of the state for the purpose of implementing state policies. Even then, however, one might appeal to the private law analogy of separately incorporated subsidiaries. The subsidiary may exist for the benefit of the parent, but that does not mean that the parent is made liable for the debts of the sub. The reasons for limited liability in the case of wholly-owned subsidiaries are admittedly weak, ${ }^{77}$ but there does not appear to be any reason to differentiate between municipal and private corporations on this issue.

\section{E. Lien on Future Tax or Other Revenues}

Another remedy available to creditors in the private context is to garnish a future stream of income. What would it mean to garnish the future income of a municipality? It would be to garnish payments owing to the city from private parties (before they are remitted to the city), or to obtain a lien on tax revenues. As to payments from private parties, the courts treated them as identical to execution against city property: that is, if the payments were made for general public purposes there could be no garnishment. ${ }^{78}$ Thus, in a typical case, a tort judgment creditor attempted to garnish insurance proceeds owed to Pratt City, Alabama, as the result

7s Id at 332 .

76 Id at 331 .

77 See Blumberg, $11 \mathrm{~J}$ Corp $\mathrm{L}$ at $623-26$ (cited in note 62 ).

78 Where bonds are secured by the revenues of a special fund, the bondholders were recognized as having a right to receive those revenues and to block diversion of those revenues to other nurposes, including the payment of general obligations of the municipality. Seẻ United Stätes Trust Co. $v$ New Jersey, $431^{\circ} \mathrm{US}$, I7-32 (1977). This principle retains force under the Bankruptcy Code. Matter of Sanitary \& Improvement District No. 7, 98 Bankr 970, 974 (D Neb 1989) (Bankruptcy Code provides that "the lien on a stream of payments from the governmental entity to revenue bondholders was not cut off by the filing of bankruptcy"). 
of a fire in certain public buildings. Notwithstanding the fact that the buildings had already been rebuilt with other funds and the insurance proceeds would therefore become part of the general treasury, the Alabama Supreme Court held that garnishment was barred by the "public purpose" doctrine. ${ }^{79}$ On the other hand, the same court in another case ordered garnishment of the proceeds of the sale of city property not used for public purposes. ${ }^{80}$

A similar rule applied to garnishment of tax receipts. For example, in Underhill $v$ Calhoun, ${ }^{81}$ a judgment creditor filed suit against a taxpayer who had given a note to the city for payment of back taxes. The Supreme Court of Alabama held that "the taxes and public revenues of [municipal] corporations cannot be seized under executions against them, either in the treasury, or when in transit to it." ${ }^{82}$ The court frankly acknowledged that this rule was contrary to "moral sense," but found it to be necessitated by "public policy," in order to avoid "the disorder which would be thereby produced in public accounts and administration."83 The United States Supreme Court proffered a more formalistic explanation for the rule. Until taxes are collected, the Court stated, they "have none of the elements of property which can be seized like debts by attachment or other judicial process" and are thus "in no proper sense of the term assets of the corporation."

Whatever its justification, the result is consistent with the rule that creditors could not attach monies held in the public treasury, which might be needed for the public good. If the funds could not be attached once collected, it made little sense to say they could be attached before they were collected. In effect, this implies that the public good (as determined by the political processes of the city) had automatic priority over the creditors. We should also note that seizures of cash, future tax revenues, or debts owed to the city often would not pose many of the risks associated with seizure of other assets. The central concern is that seizures will separate efficient combinations of assets-the generalized version of a left shoe

79 Ellis v Pratt City, 111 Ala 629, 20 S 649, 650-51 (1896).

so Murphree $v$ City of Mobile, 108 Ala 663, 18 S 740, 742 (1895). In Canal \& Claiborne Streets Railroad Co. $v$ Hart, 114 US 654 (1885), the United States Supreme Court affirmed a garnishment order directed to a company that owed monthly payments to the City of New Orleans; but in that case, the defendant had not properly raised the argument that "the debt of the corporation to the city was part of its public revenues, and not subject to seizure or levy," so the decision cannot be taken as precedent on the point. Id at 662-63.

${ }^{81} 63$ Ala 216 (1879).

82. Id at 218.

s3 Id at 217-18.

s Meriwether, 102 US at 514. 
and a right shoe. This may mean separating computer hardware from software, printing press from plates or any of the other myriad of possibilities. Cash, of course, is fungible. That makes it unlikely that an asset synergy will be destroyed by its seizure. To be sure, we should still worry about the incentives of creditors to attempt to seize cash. A rule that bars such seizures prevents duplicative races to the cash, and such races may be wasteful in and of themselves. The only point to note is that the case against seizure is probably weaker for future taxes than it is for other city assets.

\section{F. Imposition of New Taxes}

None of the creditors' remedies thus far discussed provided much succor to the municipal creditor. Most were legally unavailable. Those that were available at all were limited to special circumstances, required special authorization, or were of little practical use. The principal remedy, in practice, was one that has no analogy in private law: the issuance of a writ of mandamus requiring imposition of new taxes. ${ }^{85}$ As described by the Supreme Court in the Memphis default case:

When creditors are unable to obtain payment of their judgments against municipal bodies by execution, they can proceed by mandamus against the municipal authorities to compel them to levy the necessary tax for that purpose, if such authorities are clothed by the legislature with the taxing power; and such tax, when collected, cannot be diverted to other uses. ${ }^{86}$

From a modern perspective, it may seem odd that courts deemed themselves powerless to require cities to cut spending, sell property, or turn over funds on hand because these directives would intrude too deeply into the political discretion of municipal authorities, but felt free to order a tax increase at the behest of private parties-thus removing from political control a matter

8s Dillon, 4 Commentaries on Municipal Corporations $\S 1506$ at 2673 (cited in note 57). See, for example, Maryland Casualty Co. v Leland, 214 NC 235, 199 SE 7, 9 (1938) ("From earliest times in this State, and generally elsewhere, mandamus has been recognized as a proper proceeding to compel a levy of tax to pay a judgment against a municipality. ... . In fact, it is often the only remedy . . . ."). See also Hasley $v$ City of Chicago, $25 \mathrm{Ill}$ 595, 598 (1861).

s Meriwether, 102 US at 518. The continuing vitality of the mandamus remedy was recently confirmed by the Supreme Court, in dicta, in considering the power of a federal district court judge to raise property taxes as part of a remedial scheme for past desegregation. See Missouri v Jenkins, 495 US 33, 56-58 (1990). 
which from the days of the American Revolution and the earlier struggles of Parliament against the King was considered at the heart of republican government..$^{87}$ But the courts understood this process not as interfering with the political discretion of the city officials (as would blocking needless expenditures) but as enforcing a plain duty imposed by other authority. The courts made clear that the judiciary has absolutely no power to exercise the taxing power. Indeed, in the very same case in which the mandamus remedy was described in the previous paragraph, the Court pronounced: "The levying of taxes is not a judicial act. It has no elements of one. It is a high act of sovereignty, to be performed only by the legislature upon considerations of policy, necessity, and the public welfare." 88 The duty to levy taxes was not imposed by the courts, but merely enforced by them. Where did the duty come from?

In the typical case, the duty was imposed by state law. The Illinois Constitution of 1870, for example, provided that the general assembly "shall require that all the taxable property within the limits of municipal corporations shall be taxed for the payment of debts contracted under authority of law,"89 and further required "[a]ny county, city, school district, or other municipal corporation [ ] incurring any indebtedess ... [to] provide for the collection of a direct annual tax sufficient to pay the interest on such debt as it falls due, and also to pay and discharge the principal thereof within twenty years of the time of contracting the same." ${ }^{90}$ The General Assembly discharged its responsibility by enactment of the Cities and Villages Act of 1872, which required cities to include payments on debt "to the sum authorized to be raised in the next general tax levy."91 Another common approach was to incorporate a requirement of this sort in the municipal charter. ${ }^{92}$ In most states, therefore, the duty to levy taxes for the payment of munici-

\footnotetext{
${ }^{87}$ Such an argument was made and rejected at the time. See, for example, Commonwealth ex rel Armstrong $v$ Commissioners of Allegheny, $37 \mathrm{~Pa} 277,291-92$ (1860) (rejecting argument that "the exercise of the taxing power invoked by the relator, is an act of sovereignty resting in the will of the respondents [county commissioners], and cannot be coerced").

${ }^{88}$ Meriwether, 102 US at 515.

${ }^{80}$ Ill Const of 1870 , Art IX, $\$ 10$.

so Id at Art IX, § 12.

${ }^{91}$ Illinois Cities and Villages Act of 1872, Art 7, § 5 .

${ }^{92}$ See, for example, Commonwealth ex rel Hamilton $v$ Select and Common Councils of Pittsburgh, $34 \mathrm{~Pa} 496,513$ (1859).
} 
pal debts was a matter of explicit state constitutional and statutory law. ${ }^{93}$

In other instances, the borrower would commit itself to levy necessary taxes as part of the debt instrument itself. In these cases the duty was self-imposed and made irrevocable by force of federal constitutional law under the Contracts Clause. Indeed, since imposition of taxes was the only means by which a creditor could expect to be paid, it would have been difficult for a city to find takers for a bond issue if there were no judicially-enforceable obligation under either state law or contract to levy taxes for payment of principal and interest.

Even in the absence of an express statutory obligation or contractual undertaking to raise necessary taxes, this seemed so obvious a part of the obligation that courts were willing to interpret the relevant instruments to authorize the mandamus remedy on the ground that the duty to levy taxes is implied by the power to issue debt. ${ }^{94}$ This did not mean, of course, that the duty was judicially imposed-it was simply a matter of interpretation in light of common expectations. Where there was a specific negative or negative implication, mandamus would not lie, for the courts had no authority to order imposition of new taxes if there was no plain duty under state law or contract. For example, in United States $v$ Macon County, ${ }^{26}$ the act authorizing the issuance of bonds provided for a tax of one-twentieth of one percent of assessed value for satisfaction of the debt. The Supreme Court applied the maxim expresssio unius est exclusio alterius to negate any implication of a duty to impose a tax in excess of that level. ${ }^{96}$ Moreover, a city could not circumvent limitations on its taxing authority by the device of borrowing: there could be no enforcement of debt where the obligation did not arise under state law. ${ }^{97}$ Thus, in states in which

9s Most federal mandamus cases were of this sort. See, for example, Graham v Folsom, 200 US 248, 249 (1906) (bonds issued under state statute providing that the municipal officers "shall be authorized and required to assess an annual tax upon the property" within the municipality to pay the debt).

9 Scotland County Court v Hill, 140 US 41, $44-47$ (1891); United States v New Orleans, 98 US 381, 397 (1878); Commonwealth ex rel Armstrong, $37 \mathrm{~Pa}$ at 284, 290; Dillon, 4 Commentaries on Municipal Corporations $\S 1508$ at 2681-84 (cited in note 57).

${ }^{95} 99$ US 582 (1879).

96 Id at 590 .

${ }^{97}$ The question of state law authorization was determined as of the time of the contract. For a state to deprive the city of its taxing power after the debt had been contracted was deemed to be an impairment of the obligation of contract. Van Hoffman $v$ City of Quincy, 71 US 535, 549-55 (1866). See also Deere v Rio Grande County, 33 F Supp 823, 824 (D Colo 1888). 
the tax sources or maximum tax rates for the purposes of repaying debt were limited by state law, ${ }^{88}$ creditors could not obtain mandamus for any additional taxation.

For much the same reason, judgment creditors on noncontractual debts might have no effective remedy at all. In the absence of a state law compelling the imposition of taxes for payment of judgments, a city could indefinitely postpone payment of noncontractual obligations by the simple strategem of appropriating all revenues to other public purposes. ${ }^{99}$

At times of general financial distress, the mandamus remedy had serious practical drawbacks. To begin with, the power of the court extends only to those obligations held by parties to the suit, which means that a single filing by an impatient creditor will trigger an avalanche of suits by bondholders who do not wish to be last in line. This rush to collect through the mandamus remedy replicates many of the concerns that made it sensible to insulate city assets from seizure in the first place. ${ }^{100}$ Second, the raising of tax rates does not necessarily produce more revenue. The new taxes tend to be resented and delinquency rates soar. With high rates of delinquency, the only option available to creditors and courts is to raise rates yet again, which exacerbates delinquencies and effectively destroys the fiscal base of the city. Unusally high rates of taxation also discourage economic activity and create an incentive for business and higher income taxpayers to depart the jurisdiction. Wealthier citizens and business are not only very sensitive to changes in tax rates but are also the groups most capable of relocating in order to escape the new tax burden. ${ }^{101}$ Third, the enforcement of taxes through widespread tax sales of property is a grim prospect, since the combination of high tax rates and numerous sales can cause the bottom to drop out of the market. Mandamus thus works best if used only to enforce discrete obligations unpaid by the city; it can become counterproductive in the case of a general inability to pay. Yet in theory, the mandamus remedy was generally deemed nondiscretionary, which meant that courts had no choice but to raise tax levies, ${ }^{102}$ even to unrealistically high

\footnotetext{
${ }^{88}$ See, for example, Ark Const, Amend 62, $\S \S 1$ and 2.

${ }^{28}$ Louisiana $v$ Mayor of New Orleans, 109 US 285, 287-90 (1883). For a more recent example, see Bullis $v$ Town of Jackson, 4 S2d 550, 553 (La Ct App 1942). This may still be possible. See Evans v City of Chicago, 873 F2d 1007, 1017-18 (7th Cir 1989).

${ }^{100}$ See text accompanying notes 19-26.

${ }_{101}$ See Richard-Briffault, Our Localism: Part II-Localism and Legal Theory, 90 Colum L Rev 346, 408 (1990).

${ }^{102}$ See Maryland Casualty Co $v$ Leland, 214 NC 235, 199 SE 7, 9-10 (1938).
} 
levels (though by the depth of the Depression, courts began to exercise equitable discretion ${ }^{103}$ ).

Levels of taxes and delinquency rose to sometimes astonishing levels during the Depression. In West Palm Beach, the property tax rose to over forty percent of assessed valuation, of which only about seven percent went for the operations of the city and the rest to debt service. ${ }^{104}$ In Asheville, North Carolina-even after slashing operating expenditures by half between 1931 and 1934 - the city's debt burden was eighty-five percent of assessed valuation, and tax delinquencies soared from twenty-one percent to fifty-eight percent. ${ }^{105}$ In Detroit in 1932, seventy-six percent of tax revenues went to debt service and the tax delinquency rate was thirty-six percent, or $\$ 28$ million. Mayor (and future Supreme Court Justice) Frank Murphy told Congress that, without relief, the delinquency rate might rise to eighty percent. ${ }^{106}$

Creditors thus had an incentive to negotiate debt relief, for to invoke the only real legal remedy, mandamus, could precipitate a financial meltdown that would leave creditors worse off than before. But the final, and most serious, practical difficulty was the absence of legal means to prevent holdouts from refusing to cooperate with the compromise solution. Often they would insist on obtaining more favorable terms than other creditors, which then caused even willing compromisers to withdraw from the deal. A representative of the organized creditors of fifty municipalities testified to Congress:

We usually try to reach an agreement with the city officials as to what they are going to do in the way of meeting their obligations. ... We have, perhaps, anywhere from 75 to 95 percent of the creditors who accept that settlement and then a small minority will hold out and will prevent us from consummating the settlement; we are never able to consummate it, because of the few creditors who hold out and demand 100 cents on the dollar and, if we were to accept new obligations on the refunded basis and extend our maturity for a long period, it would simply enable them to come in and get a writ of

${ }^{203}$ Faitoute Co. v Asbury Park, 316 US 502, 507-09 (1942).

104 Hillhouse, Municipal Bonds at 280 (cited in note 38).

${ }_{10 s}$ Advisory Commission on Intergovernmental Relations, City Financial Emergencies: The Intergovernmental Dimension 21 (1973).

${ }_{108}$ Hearings on HR 1670, HR 3083, HR 4311, HR 5009, and HR 5267 before the House Committee on the Judiciary, 73d Cong, 1st Sess 86 (1933) (statement of Mayor Frank Murphy). 
mandamus to require a tax levy to settle in full for their bonds and make a further tax levy impossible to collect and endanger the refunding bonds and perhaps precipitate a default immediately on the new bonds. Consequently, the majority creditors do not dare to consummate the contract which has been agreed upon; neither does the municipality feel that they can consummate it until those creditors have been brought in line. ${ }^{107}$

State law could not remedy this problem, because forcing an unwilling creditor to compromise his claim would be an unconstitutional impairment of the obligation of contract.

In theory, a state could authorize its cities to restrict the availability of the mandamus remedy if it did so prospectively. Thus it might seem that the mandamus problem was self-inflicted, or at least the product of insufficient foresight. In reality, however, cities had little choice. Since there were no other effective creditors' remedies, and since mandamus had come to be the standard, a city that restricted the remedy prospectively would probably find itself barred from the credit markets. The only solution was to change the terms of the contract after the fact, a course of action prohibited by the Contracts Clause. It was the necessity of changing contracts after the fact and the difficulty of doing so with a large number of creditors that led to the creation of a federal municipal bankruptcy act.

\section{Federal Municipal Bankruptcy Law}

\section{A. Passage of the Original Act}

The first federal municipal bankruptcy statute, passed in 1933, was designed solely to deal with the holdout problem that arose when individual creditors threatened to scotch negotiated debt plans that were in the best interests of the debtor and the creditors as a group. As explained by its principal sponsor:

The object and purpose of the bill is, of course, to enable counties, towns, and tax districts to adjust their debts effectively. In every instance where a governmental unit finds itself in financial difficulty and is able to make some satisfactory agreement of adjustment with the majority of its creditors, there is always a small minority who hold out and demand preferential treatment. These minority creditors are prompted

${ }^{107}$ Id at 45 (statement of David M. Wood). 
in this action by the thought that someone will buy them out rather than have the whole plan collapse. The difficulty, of course, is that if one creditor by holding out can gain preferential treatment the others withdraw and nothing comes of the efforts at settlement or adjustment. It is to remove this difficulty that the bill has been drawn and introduced. If this bill is enacted, the minority creditors will be forced to accept the terms of adjustment which have been agreed upon by the officials of the political subdivision and the vast majority of creditors and approved by the court as being fair and equitable. ${ }^{108}$

The bill was passed at the instance of municipal officials, with the acquiescence of representatives of the creditor class: trust estates, insurance companies, endowment funds, pension funds, and other major holders of municipal bonds. ${ }^{109}$

Under the bill, municipalities were permitted (not required) to negotiate settlements of their debts with their creditors. The bill did not permit the court to assume jurisdiction or control over the expenditures, property, or other governing powers of the municipality. Only if the settlement was approved by a certain percentage of the creditors (seventy-five percent in the initial bill) could it be imposed on the minority creditors. As a further safeguard, the court was required to determine that the settlement plan was fair and equitable, and the bill was limited to municipalities that had authority under state law to take advantage of its provisions.

By a 5-4 vote, the Court struck down this first federal municipal bankruptcy statute on constitutional grounds in Ashton $v$ Cameron County District,"10 on the theory that it "might materially restrict respondent's control over its fiscal affairs."111 The Court elaborated that "[i]f obligations of States or their political subdivisions may be subjected to the interference here attempted, they are no longer free to manage their own affairs; the will of Congress prevails over them."112

The reasoning of this decision is exceptionally weak. While a plausible argument against the Act might have been based on the rights of the creditors (perhaps that Congress could not extend its

\footnotetext{
108 Id at 22 (statement of Rep. J. Mark Wilcox).

${ }^{109}$ Id at 40 (testimony of Charles Taylor, spokesman for Metropolitan Life Insurance Company).

110298 US 513 (1936).

111 Id at 530 .

112 Id at 531.
} 
own Contracts Clause immunity to a state or local government), the federalism-based reasoning of Ashton is impossible to defend. The federal act carefully preserved local control over fiscal decisions from judicial interference, as well as state power over. whether localities could take advantage of it. All the Act did was to free cities of the limitations of the Contracts Clause and enable them to negotiate settlements with their creditors without the holdout problem. It is hard to see how the "will of Congress" is made to prevail over the cities; on the contrary, cities are given an additional tool for the management of their own affairs. Even granting the underlying constitutional premise of dual federalism (which is no longer given strict application), the Ashton decision seems unnecessary and misguided.

Congress thought so too. The year after Ashton, Congress enacted a new municipal bankruptcy statute only slightly different from the invalidated one. The statute was promptly challenged, but this time it was upheld (over a dissent by the author of the Ashton opinion). ${ }^{113}$ In his argument before the Court, Solicitor General Robert Jackson all but admitted that the sections of the statute applicable to political subdivisions of the State would be unconstitutional under Ashton, but quoted a member of Congress to the effect that "it was not only the right, but the duty of Congress to present the question once more to this Court, since the decision, if allowed to stand, threatened grave impairment to the powers of the States."114 While not expressly overruling Ashton, the Court upheld the new Act without identifying any specific points of distinction from the earlier Act. This time, the Court understood the Act not as in derogation of state and local sovereignty, but as "in aid" of those powers. ${ }^{115}$ According to the Court, "[i]t is of the essence of sovereignty to be able to make contracts and give consents bearing upon the exertion of governmental power," and the bankruptcy statute removes an obstacle to doing so. ${ }^{116}$ The Court was also impressed with the practical exigencies of the situation, in which the cities were in "distress," the power of taxation was "useless," and the creditors were "helpless." "The natural and reasonable remedy through composition of the debts of the district was not available under state law by reason of the restriction imposed by the Federal Constitution upon the impair-

113 United States $v$ Bekins, 304 US 27 (1938).

114 Id at 33 (argument for the United States).

215 Id at 54.

118 Id at 51-52. 
ment of contracts by state legislation. The bankruptcy power is competent to give relief to debtors in such a plight."117 The Court indicated that the only possible constitutional obstacle might lie in the right of the State to prevent a municipality from seeking bankruptcy protection-an argument not relevant to this case, where the State had consented.

The only changes of constitutional interest between the 1933 Act and the 1937 Act were that the 1937 Act (1) omitted the express provision of the 1933 Act requiring the approval of the bankruptcy petition by the State, replacing it with the requirement that a petitioning municipality show that it "is authorized by law to take all action necessary to be taken by it to carry out the plan,"118 and (2) excluded counties from the Act. The former change cannot account for the change of result, because it diminished the power of the state, thus exacerbating any federalism-based problems. The change was, however, of little significance, since states still retained the power to prevent their cities from declaring bankruptcy. ${ }^{119}$ The main effect is to generate more uncertainty. ${ }^{120}$ The latter change is interesting in that it implies that Congress considered counties to stand on a different constitutional footing than other municipalities. In traditional state constitutional law, counties are not municipal corporations, but are essential subdivisions of the State and thus more closely resemble sovereign entities. It might make sense to differentiate counties from municipal corporations for purposes of ordinary bankruptcy, because counties cannot be dissolved (the entire area of a state is usually divided into counties), while municipal corporations can (it is possible for areas to be unincorporated). The distinction was of no relevance to the 1933 and 1937 Acts, however, since those Acts did not contemplate dissolution of the municipal corporation but simply composition of the debts, a remedy that is equally applicable to counties. In any event, Congress amended the Act in 1946 to include counties, ${ }^{121}$ and the distinction has no importance today.

The constitutional law of municipal default was further transformed in 1942, in Faitoute Iron \& Steel Co. $v$ Asbury Park. ${ }^{122}$ Prior to Faitoute, it was assumed that states were incompetent to

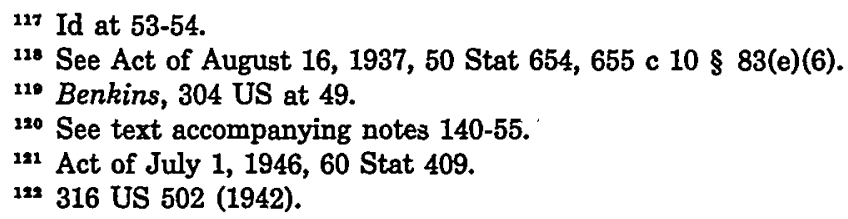


provide relief for municipal debtors because any plan of involuntary composition of the debts would impair the obligation of the creditor's contract, in violation of the Contracts Clause. Indeed, in upholding the 1937 Act, the Court had noted that a federal statute was necessary precisely because the Contracts Clause precluded states from passing laws for the composition of municipal debts. ${ }^{123}$ In Faitoute, however, the Court upheld a 1933 New Jersey law that permitted a plan of adjustment of municipal debt over the objection of minority creditors, if the city and eighty-five percent of the creditors agreed. The Court reasoned that such plans, viewed realistically, do not impair the obligation of contract but rather are "the only proven way for assuring payment of unsecured municipal obligations."124 The traditional remedy of mandamus, the Court said, was "empty."125 And indeed, the municipal bonds in question increased in value from sixty-nine to more than ninety cents on the dollar after the plan of adjustment went into effect. ${ }^{126}$ Thus the state law, much like the federal, was premised on the notion that both creditor and debtor would be made better off by allowing refinancing of the debt, if only the problem of minority holdouts could be overcome. ${ }^{127}$

\section{B. The Current Chapter 9 of the Bankruptcy Code}

Municipal bankruptcy law thus originated from a desire to control minority holdouts, and arose in a context of substantial uncertainty over the appropriate relationship between federal and state law. These issues still resonate in the current Chapter 9. We look at four issues of particular interest in Chapter 9: (1) its petition filing requirements; (2) the scope of debtor autonomy; (3) its plan confirmation rules; and (4) the status of collective bargaining agreements.

${ }^{123}$ Bekins, 304 US at 54.

124 Faitoute, 316 US at 512.

125 Id at 515.

${ }^{128}$ Id at 513.

127 The specific holding of Faitoute was reversed by Congress: federal law now prohibits states from exercising any power they might have to compel composition of municipal debt. See 11 USC $\S 903(1)$ (1988). In these authors' judgment, this feature of the Act is far more questionable on federalism grounds than was the 1933 Act. For further discussion of its practical implications, see text accompanying notes $222-28$. 


\section{Filing under Chapter 9.}

Federal bankruptcy law ${ }^{128}$ is divided into chapters, odd chapters, at that (save for an even-numbered chapter for family farmers added in $1986^{129}$ ). Chapter 9 covers municipalities, but the single most important provision for municipal bankruptcy is set forth in $\S 109$ (c), which serves as the gatekeeper for filings under Chapter 9. ${ }^{130}$ Only municipalities may file under Chapter 9 and they cannot file elsewhere. ${ }^{131}$ Municipalities, like farmers and charitable corporations, are not subject to an involuntary bankruptcy petition. ${ }^{132}$ To the bankruptcy newcomer, § 109(c) may appear unremarkable: other than the requirement that the debtor be a municipality, ${ }^{13 s}$ the section requires only that the debtor be insolvent, have worked out a plan to deal with its debts or have failed in trying, and be authorized to file for bankruptcy. Subsection (c) becomes interesting only when contrasted with the rest of $\S 109$.

Other debtors face fewer impediments to filing. For example, we do not insist that other debtors filing voluntarily meet any

128 The Bankruptcy Reform Act of 1978, 11 USC $\S \S 101$ et seq, as amended (1988 \& supp 1991).

${ }_{120}$ Family Farmer Bankruptcy Act of 1986, 11 USC $\$ 1201$ et seq (1988).

130 Section 109(c) provides that:

(c) An entity may be a debtor under chapter 9 of this title if and only if such entity-

(1) is a municipality;

(2) is generally authorized to be a debtor under such chapter by State law, or by a governmental officer or organization empowered by State law to authorize such entity to be a debtor under such chapter;

(3) is insolvent;

(4) desires to effect a plan to adjust such debts; and

(5) (A) has obtained the agreement of creditors holding at least a majority in amount of the claims of each class that such entity intends to impair under a plan in a case under such chapter;

(B) has negotiated in good faith with creditors and has failed to obtain the agreement of creditors holding at least a majority in amount of the claims of each class that such entity intends to impair under a plan in a case under such chapter;

(C) is unable to negotiate with creditors because such negotiation is impracticable; or

(D) reasonably believes that a creditor may attempt to obtain a transfer that is avoidable under section 547 of this title.

131 The "if and only if" language in $\S 109(\mathrm{c})$, has the effect of making municipalities eligible under Chapter 9 and limiting Chapter 9 to municipalities. To conclude that municipalities cannot file under Chapters 7 or 11 takes a bit more work. Section 109(b) establishes eligibility for filings under Chapter 7 and limits that to "persons," defined in $\S 101(41)$. This definition excludes governmental units, which (as defined in $\S 101(27)$ ) includes municipalities. Chapter 11 eligibility under $\S 109$ (d) is defined through Chapter 7 eligibility, and therefore a municipality is not eligible under either Chapter 7 or Chapter 11.

${ }^{132} 11$ USC \$ 303(a) (limiting involuntary petitions to cases under Chapter 7 or 11).

133 "Municipality" is defined as a political subdivision or public agency or instrumentality of a State. 11 USC § 101(40). 
threshhold test of solvency. As bankruptcy has become more familiar, the cry has gone out that debtors now abuse the process, and that even solvent companies may find it worthwhile to file for bankruptcy. ${ }^{134}$ Nonetheless, only a municipality faces a statutory requirement of insolvency. In this context, insolvency means that the municipal debtor either currently cannot pay its debts as they become due-the bills arrive and cannot be paid-or that the debtor will not be able to pay such debts as they become due-bills will arrive in six months and cannot be paid then. ${ }^{135}$ This is a cash flow insolvency test. The test for current insolvency is akin to the test for an involuntary petition set out in $\S 303(\mathrm{~h})$, but the prospective cash flow test appears nowhere else in the Bankruptcy Code. ${ }^{136}$ Both tests differ from the balance sheet insolvency test used in most other bankruptcy contexts: for municipal debtors the Code looks to cash flow, while for other debtors it looks to assets and liabilities. ${ }^{197}$ A city may be "insolvent" even if it has extensive and valuable assets. This reflects the pre-Code common law view, which treated the municipal debtor as having few physical assets available for creditors and instead focused almost exclusively on the ability of the debtor to generate revenues through property taxes. ${ }^{138}$

The insolvency standard delays and discourages municipal bankruptcy filings and thus serves as an effective gatekeeper. For example, in the most prominent municipal filing since adoption of the 1978 Code, Bridgeport, Connecticut, was running a $\$ 16$ million annual deficit, had the highest effective tax rates in the State, and was in dire financial straits. But it had not yet exhausted its borrowing power and thus would not "run out of cash" in the next fiscal year. The court accordingly held that it was not insolvent. ${ }^{139}$ While the gatekeeper function reduces the moral hazard of easy debt relief, the insolvency standard almost certainly makes both creditors and debtor worse off in those cases actually culminating in bankruptcy. It postpones the day of reckoning, while the city continues to pile on new debt at ever-increasing interest rates, fur-

\footnotetext{
134 See, for example, Frank R. Kennedy, Creative Bankruptcy? Use and Abuse of the Bankruptcy Law-Reflection on Some Recent Cases, 71 Iowa L Rev 199 (1985).

13511 USC \& 101(32)(C).

${ }^{138}$ See In re City of Bridgeport, 129 Bankr 332, 336-37 (Bankr D Conn 1991); In re Villages at Castle Rock Metro. Dist No. 4, 145 Bankr 76, 84 (Bankr D Colo 1990). See also the discussion in Dubrow, 24 Urban Law at 557-60 (cited in note 1).

${ }^{237}$ See 11 USC \& 101(32)(A),(B).

${ }^{138}$ See the discussion of creditors' remedies at text accompanying notes 85-107.

139 Bridgeport, 129 Bankr at 337-38.
} 
ther burdening the municipal budget and guaranteeing that each creditor will receive less value in bankruptcy. The problem is not easy to solve, because the insulation of municipal assets from seizure and sale makes the idea of balance sheet insolvency meaningless, and there is no obvious alternative. We will return to this issue below.

The second important limit on municipal filings-that the state authorize the debtor to file-has roots in the constitutional principle that the federal government may not interfere with the internal governance of a state or its political subdivisions. Section 109(c)(2) preserves the power of the states to determine the extent to which their political subdivisions have access to the powers of the bankruptcy court. There was, and still may be, substantial doubt about the constitutionality of depriving a state of the power to determine which of its subdivisions can file for bankruptcy. ${ }^{140}$ Section 109(c)(2) is intended to sidestep this problem, though the actual language of the section is difficult to apply and creates needless uncertainty. Although some states authorize filings quite directly ${ }^{141}$ and at least one state bars filings, equally directly, ${ }^{142}$ most states occupy a middle ground. ${ }^{143}$

${ }^{260}$ See Bekins, 304 US at 49 (leaving open the question of whether state consent is constitutionally required).

14 See, for example, Neb Rev Stat \& 13-402 (1991):

Any county, city, village, school district, agency of the state government, drainage district, sanitary and improvement district, or other political subdivision of the State of Nebraska is hereby permitted, authorized, and given the power to file a petition in the United States Bankruptcy Court under 11 U.S.C. chapter 9 and any acts amendatory thereto and supplementary thereof and to incur and pay the expenses incident to the consummation of a plan of adjustment of debts as contemplated by such petition.

142 See Ga Code Ann § 36-80-5 (Michie 1987):

(a) No county, municipality, school district, authority, division, instrumentality, political subdivision, or public body corporate created under the Constitution or laws of this state shall be authorized to file a petition for relief from payment of its debts as they mature or a petition for composition of its debts under any federal statute providing for such relief or composition or otherwise to take advantage of any federal statute providing for the adjustment of debts of political subdivisions and public agencies and instrumentalities.

(b) No chief executive, mayor, board of commissioners, city council, board of trustees, or other governmental officer, governing body, or organization shall be empowered to cause or authorize the filing by or on behalf of any county, municipality, school district, authority, division, instrumentality, political subdivision, or public body corporate created under the Constitution or laws of this state of any petition for relief from payment of its debts as they mature or a petition for composition of its debts under any federal statute providing for such relief or composition or otherwise to take advantage of any federal statute providing for the adjustment of debts of political subdivisions and public agencies and instrumentalities.

${ }^{143}$ One commentator puts the numbers at seventeen authorizing, one barring and the rest in the squishy middle. See Jeffrey Cohen, Declining Health of U.S. Cities Raises New 
In the Bridgeport case, the city was held to have state authorization to file for bankruptcy despite the strenuous opposition of the state itself. ${ }^{144}$ The court found authorization in the general power to sue and be sued and was not deterred by the state's passage of a Special Act establishing a Financial Review Board to oversee Bridgeport's financial affairs and to restore the city to financial stability, nor by the opposition of that Board to the bankruptcy petition. It is for states-like Connecticut-that lack express provisions either way that the "generally authorized" language must be interpreted (read, must be litigated). ${ }^{145}$

The court's evidently high opinion of bankruptcy carried the day, an approach impossible to reconcile with the statute's deference to state law. A better approach would be to presume that home rule jurisdictions are authorized to file, in the absence of contrary state law, and to require specific authorization in other cases. ${ }^{148}$ Under the traditional understanding of municipal power, cities are strictly limited to the powers vested in them by state legislatures, and any substantial doubt about the existence of

Interest in Chapter 9, Natl L J 15 col 1 (Aug 5, 1991). Looming in the background of this issue, but not resolved in litigation, is whether general state constitutional provisions requiring municipalities to make adequate provision for the payment of debts should be intepreted as barring bankruptcy filings. See Flushing National Bank v Municipal Assistance Corp., 358 NE2d 848, 40 NY2d 731 (1976). If so, Chapter 9's availability may be far more constricted than is usually thought.

144 Bridgeport, 128 Bankr at 698-99. The City of Bridgeport deserves special mention in any account of the history of municipal bankruptcy. In the 1830s, Bridgeport found itself in financial difficulties, and sought ways to avoid payment of its debts by claiming that the debts had not been lawfully incurred and were not judicially enforceable. In response, the Connecticut legislature enacted a statute providing that the securities issued by the city would be legally enforceable, and the Supreme Court of the State subsequently held that creditors could seize the private property of the city's inhabitants to pay the debts. Beardsley v Smith, 16 Conn 368, 376 (1844). Eighty years later, in 1925, the City again was on the brink of default. This time the State averted financial disaster by stripping local officials of their authority over the financial affairs of the city and by establishing a blue-ribbon board of commissioners with the power to revise and approve city budgets and to appoint and supervise the tax assessor. The commissioners served without compensation and restored the City to financial soundness by the end of 1931 . Their success made the Bridgeport receivership a nationwide model. Hillhouse, Municipal Bonds at 326-27 (cited in note 38). Yet 60 years later, Bridgeport earned the distinction of being the first large American city to file for bankruptcy under the Code.

145 For a representative sample, see Bridgeport, 128 Bankr at 693-96; Castle Rock, 145 Bankr at 82-84; In re City of Wellston, 43 Bankr 348, 350 (Bankr E D Mo 1984); In re Pleasant View Utility Dist. of Cheatham Cty., 27 Bankr 552, 553 (Bankr M D Tenn 1982).

${ }^{148}$ For a related proposal, see Eric W. Lam, Municipal Bankruptcy: The Problem With Chapter 9 Eligibility-A Proposal to Amend 11 U.S.C. $\&$ 109(c)(2) (1988), 22 Ariz St L J 625, 635-37 (1990). 
power should be resolved against it. ${ }^{147}$ In such a system, a city should not be permitted to file for bankruptcy without specific permission from the state, and vague language such as the right to "sue and be sued" should not be stretched to cover the case. By contrast, home rule powers typically extend to all matters that are "local and municipal" in character, ${ }^{148}$ or that are "not denied" by its charter or by state law. ${ }^{148}$ The power to file for bankruptcy is a natural element of the autonomy enjoyed by home rule jurisdictions. Even in home rule jurisdictions, however, courts should give effect to state law abrogating the right, unless such law is itself subject to challenge under the state constitution. ${ }^{180}$ Nonetheless, in the general case, in the absence of state constitutional issues of this sort, when a state has passed specific legislation addressing the situation of a distressed municipality, it should be presumed to occupy the field, and the court should not allow federal bankruptcy law to interfere with the state's plan. ${ }^{151}$

The Bridgeport decision may serve as a negative example. The Bridgeport Special Act gave the Financial Review Board certain supervisory powers over the city's financial affairs "in order to maintain access to public credit markets, to fund the city's accumulated deficits and to restore financial stability to the town and city of Bridgeport."152 The stated intention to enable the city "to fund [its] accumulated deficits" suggests that the State wished to avoid bankruptcy; but the court found "no reason to believe that a bankruptcy case is inconsistent with the purposes of the Special Act, i.e., the restoration of financial stability through enhanced access to public credit markets. Indeed, the restoration of the financial stability of a troubled city is precisely what Congress designed

${ }^{247}$ See Dillon, 1 Commentaries on Municipal Corporations § 237(89) at 448-55 (cited in note 57).

${ }^{248}$ See, for example, Colo Const, Art XX, § 6; Maine Const, Art 8, Part 2d, § 1.

14: See, for example, Pa Const, Art 9, § 2; SD Const, Art IX, § 2.

150 In addition to vesting home rule powers in qualifying municipalities, some state constitutions restrict the power of the state legislature to pass supervening legislation. Others do not. Whether interference with the bankruptcy power would fall within the former protections is a matter that must be addressed on a state-by-state basis. Under the Connecticut Constitution, the question would be whether the Bridgeport Special Act is a "matter of purely local concern." Conn Const, Art Tenth. In view of the traditional state involvement with issues of local indebtedness and the potential statewide impact of default, we consider this an unlikely interpretation.

162 For a contrary argument that state legislation arguably nullifying the home rule power to file for bankruptcy should be narrowly construed, see Rachel E. Schwartz, This Way to the Egress: Should Bridgeport's Chapter 9 Filing Have Been Dismissed?, 66 Am Bankr L J 103, 126-27 \& n 124 (1992).

${ }^{132}$ Conn Special Act No 88-80, § 1, quoted in Bridgeport, 129 Bankr at $691 \mathrm{n} 1$. 
chapter 9 to accomplish."153 The court's paraphrase conveniently elided the statutory language about funding the debt. More importantly, it presumed that Congress's view that bankruptcy is the best way to restore financial stability to a troubled city should take precedence over the State's contrary view. In effect, Bridgeport was attempting to use federal bankruptcy as an alternative (perhaps an escape) from the strictures of state supervision, and the courts' substantive faith in bankruptcy prevailed over the Act's careful reservation of state authority. ${ }^{154}$

States may have a substantial interest in preventing their municipalities from declaring bankruptcy. The creditworthiness of all the cities in a state may be impaired if any city walks out on its debts by filing for bankruptcy. Creditors may understand the state itself to stand ready to come to the aid of its municipalities. The possibility of state aid, or the state functioning as a quasi-guarantor, may make it easier for all of the municipalities in a state to borrow in the credit markets. A state's reluctance to aid a financially distressed municipality puts this implicit guarantee at risk; a bankruptcy filing by a municipality would be an especially visible default by the state on its implicit guarantee and would shatter the illusion of meaningful state backing. Such a filing would therefore raise credit costs for all municipalities in the state. Perhaps this explains why Connecticut resisted Bridgeport's petition so strenuously, and why so few states have been willing to allow their cities access to a federal law passed expressly for their benefit. ${ }^{135}$

There are two additional limits on filings by municipalities: $\S 109(\mathrm{c})$ imposes a procedural bar and $\S 921(\mathrm{c})$ empowers the bankruptcy court to dismiss petitions not filed in "good faith." The procedural bar mandates certain pre-filing efforts by the municipal debtor to work out its financial difficulties. It must either have reached an agreement sufficient to confirm a plan under Chapter 9, have failed to do so despite good faith negotiations, or such negotiation must be "impracticable." Again, these requirements are unique to the Chapter 9 debtor. While most private debtors do engage in pre-petition negotiations and while some do reach an agreement to be enforced through the bankruptcy

163 Bridgeport, 128 Bankr at 1702.

154 Of course, states can solve this problem by being explicit in barring access to the federal bankruptcy power. It might well be sensible for states that set up financial oversight boards to invest those boards with the discretion to determine whether the city should file.

${ }^{288}$ Compare Dennis Epple and Chester Spatt, State Restrictions on Local Debt: Their role in preventing default, $29 \mathrm{~J}$ Pub Econ 199 (1986). 
court-this is the heart of the "prepackaged plan," the latest rage in bankruptcy practice-nothing obligates private debtors to negotiate. The same holds for the good faith filing requirement. Good faith is a common requirement in the world at large and appears with some frequency in the Bankruptcy Code, ${ }^{158}$ but only in $\S 921$ (c) is an explicit good faith requirement included as a threshhold to filing. ${ }^{157}$ The case law is too sparse to cast much light on its meaning in this new procedural context.

The Bankruptcy Code thus erects serious obstacles to municipal filing beyond those faced by private debtors. Not surprisingly, there have been very few filings. From January 1972 to June 1984, municipalities filed only twenty-one petitions under Chapter $9^{158}$ - and Bridgeport is the only large city even to have attempted it. During this same period, a number of cities came close to default and required intervention into their financial affairs under state law. ${ }^{169}$ This suggests that, for most cities, federal bankruptcy law is of less importance than state procedures addressing the prospect of municipal insolvency.

It is possible-but ultimately implausible-that the statutory barriers are not the primary cause of this result and instead that fears of adverse reactions from the credit markets keep municipalities out of bankruptcy. Private debtors want to return to the credit markets as well, and yet we see no shortage of filings by them. Indeed, companies now file for bankruptcy precisely because it makes applicable the special borrowing rules of $\S 364$. It thus seems unlikely that market concerns explain the relative paucity of municipal filings.

\footnotetext{
${ }^{186}$ See, for example, $\S \S 1129(\mathrm{a})(3), 1225(\mathrm{a})(3)$, and 1325(a)(3) of the Bridgeport Act. Examples of the use of "good faith" in the Code can be found at 11 USC $\S \S 109(\mathrm{c})(5)(\mathrm{B})$, 363(m), 364(e), 542(c)-(d), 548(c), 549(c), 550(b), 550(d)(1), 727(a)(9)(B)(ii), 1113(b)(2), $1114(\mathrm{f})(2), 1125(\mathrm{e}), 1126(\mathrm{e}), \cdot 1129(\mathrm{a})(3), 1144(1), 1225(\mathrm{a})(3), 1325(\mathrm{a})(3)$.

${ }_{187}$ For an application of this standard, see Castle Rock, 145 Bankr at 81. For an interesting discussion of this issue in the Bridgeport case-where the city found itself repudiating a prior opinion of the city's bond counsel in a preliminary bond offering statement to the effect that Bridgeport was not authorized to file for bankruptcy-see Schwartz, $66 \mathrm{Am}$ Bankr L J at 130-33 (cited in note 151). The courts are not particularly fastidious about where good faith standards are used in the Code however, and a judicially-created requirement of good faith in filing may be emerging. See Lawrence Ponoroff and F. Stephen Knippenberg, The Implied Good Faith Filing Requirement: Sentinel of an Evolving Bankruptcy Policy, $85 \mathrm{Nw}$ U L Rev 919, 924-48 (1991).

${ }_{183}$ Advisory Commission on Intergovernmental Relations, Bankruptcies, Defaults, And Other Local Government Financial Emergencies 8 (1985).

138 See text accompanying notes 203-11.
} 
2. Control over the debtor during bankruptcy.

Another major difference between municipal and private bankruptcy is the degree of control exercised by the court over the debtor during the proceeding. Under the pre-1978 Bankruptcy Act, managers of non-municipal corporate debtors gave up control to a trustee under chapter X, but retained control under the other reorganization chapters, XI and XII. The Bankruptcy Code of 1978, in forming a single reorganizations chapter, Chapter 11, created defeasible control rights: the debtor controls its own affairs as the debtor-in-possession, ${ }^{160}$ but a trustee may be appointed to manage the estate for cause. ${ }^{161}$ In contrast, a trustee is mandatory in liquidations under Chapter 7 of the Bankruptcy Code. ${ }^{162}$

Chapter 9 explicitly protects the rights of the state to control its political subdivisions and the right of the municipal debtor to manage its internal affairs. Section 903 preserves the state's power to control a municipality "in the exercise of political or governmental powers," save for limiting the ability of the states to bind nonconsenting creditors to nonbankruptcy debt compositions. ${ }^{163}$ This explicit limitation was added to overturn the holding in Faitoute. The application only to political or governmental powers seems to recognize the traditional distinction in local government law between proprietary and nonproprietary activities of municipalities. ${ }^{164}$ Section 904 provides that the bankruptcy court may not interfere with the "political or governmental powers of the debtor," the "properties or revenues of a debtor" or the "debtor's use of or enjoyment of any income-producing property."105 Thus,

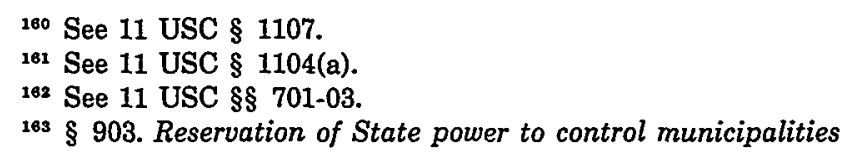
otherwise, a municipality of or in such State in the exercise of the political or governmental powers of such municipality, including expenditures for such exercise, but-

(1) a State law prescribing a method of composition of indebtedness of such municipality may not bind any creditor that does not consent to such composition; and

(2) a judgment entered under such a law may not bind a creditor that does not consent to such composition.

164 See text accompanying notes 14-42.

188

$\S 904$. Limitation on jurisdiction and powers of court

Notwithstanding any power of the court, unless the debtor consents or the plan so provides, the court may not, by any stay, order, or decree, in the case or otherwise, interfere with-

(1) any of the political or governmental powers of the debtor;

(2) any of the property or revenues of the debtor; or 
the state's power is preserved with respect to governmental functions only, while the city's power is preserved with respect to both governmental and proprietary functions. This may or may not have any practical significance, because the governmental/proprietary distinction has all but collapsed.

Taken together, sections 903 and 904 carry forward doctrines of federal common law that had governed municipal insolvency before the first federal act, ${ }^{166}$ as well as the constitutional principle against federal interference in state and local governance-a principle that has no corollary in private bankruptcy law. The effect is to preserve the power of political authorities to set their own domestic spending priorities, without restraint from the bankruptcy court. ${ }^{167}$ Of course, the states may so restrain their municipalities, within the bounds of state constitutional law. State laws dealing with the problem of distressed municipalities commonly provide for a transfer of control over municipal affairs, ${ }^{168}$ which confirms that this principle of noninterference is an artifact of federalism rather than part of the inherent autonomy of local governance.

3. Plans for the adjustment of debts.

The heart of Chapter 9 is the plan for the adjustment of the debtor's debts, just as a plan of reorganization is central to Chapter 11. The plan solves the holdout problem that gave rise to federal municipal bankruptcy. The current Chapter 9 maintains the essential structure of the original act, but the precise scope of institutional protection for creditors is unclear.

The municipal debtor controls the plan and has the exclusive right to file it. This "exclusivity" is absolute, rather than for a defined period as in Chapter 11. ${ }^{109}$ The power to confirm a plan of arrangement allows the debtor to modify the terms of existing debt

(3) the debtor's use or enjoyment of any income-producing property.

168 See text accompanying notes 14-107.

167 This overstates somewhat as the revenues-"special revenues," actually, as defined in 11 USC § 902(2)-typically associated with revenue bonds are insulated from invasion by the debtor and are thereby preserved to the bondholders to whom they have been pledged. See 11 USC \& 928. For more extended discussion, see Robert S. Amdursky, The $1988 \mathrm{Mu}$ nicipal Bankruptcy Amendments: History, Purposes, and Effects, 22 Urban Law 1 (1990).

163 See, for example, Pennsylvania Financially Distressed Municipalities Act, $53 \mathrm{~Pa}$ Cons Stat Ann § 11701.221 (Purdon, Supp 1992). See also Richard Emmett, et al, Coping with Fiscal Distress in Pennsylvania's Local Governments: A Program Evaluation of Act 47, 121-38 (Penn State, Department of Public Administration, 1991) (summarizing nine states' fiscal distress legislation). For further discussion, see text accompanying notes 20611.

2e0 Compare 11 USC § 941 with 11 USC § 1121. 
instruments. ${ }^{170} \mathrm{~A}$ plan may be confirmed if the requisite class votes are obtained, but as always in bankruptcy, the critical question is what the debtor can do over the objection of creditors. These "cramdown" powers ultimately determine the shape and scope of the plan of arrangement. They do so expressly, when the municipal debtor confirms the plan .over the objection of creditors; and they do so implicitly, when the consensual deal negotiated between the municipal debtor and the creditors reflects-as it inevitably will-the outcome that the debtor can achieve without agreement.

The standards for confirming a Chapter 9 plan are lengthy and complex. ${ }^{171}$ Nonetheless, the cramdown powers are fairly straightforward. Chapter 9 incorporates the Chapter 11 requirement that at least one impaired class of claims approve the plan. ${ }^{172}$ It also incorporates Chapter 11's cramdown protections for secured and unsecured creditors. For secured creditors, this means that they are to receive at least the value of the property securing their claims. ${ }^{173}$ For unsecured creditors, it may mean very little. The incorporated Chapter 11 standard requires that unsecured creditors either receive full payment of their claims (perhaps over time) or that holders of junior claims and interests receive nothing. In the context of the private corporation, this means that objecting unsecured creditors are entitled to be paid in full, so long as stockholders receive any value on account of their stock. Cities, however, have no stockholders. The current managers-that is, the current officeholders-owe their allegiance to the citizens who put them into control, not to the creditors. The managers need not pay off unsecured creditors to remain in control, but instead can retain control while confirming a plan giving unsecured creditors very little. In the extreme, the debtor might be able to abrogate the claims of the unsecured creditors altogether, so long as it can find an impaired class of secured claims willing to approve the plan. That is a very real possibility, given the possibility of gerrymandering classes. $^{174}$

${ }^{170}$ See, for example, In re City of Columbia Falls, Montana, Special Imp. Dist. No. 25, 143 Bankr 750, 759-61 (Bankr D Mont 1992).

${ }^{171}$ See 11 USC $\S 943$, plus the provisions incorporated by $\S 901$ from Chapter 11's standards.

${ }^{172}$ See 11 USC § 901(a) (incorporating § 1129(a)(10)).

${ }^{173}$ See 11 USC $\S 901(a)$ (incorporating $\S 1129(b)(2)(A)$ ).

${ }^{174}$ For an extended discussion of the initial disapproval of gerrymandering in the case law, its renaissance, and (perhaps) its ultimate decline, see Peter E. Meltzer, Disénfranchising the Dissenting Creditor Through Artificial Classification or Artificial Impairment, 66 Am Bankr L J 281, 281-82 (1992). 
The incorporated Chapter 11 cramdown standard is therefore of cold comfort to unsecured creditors. They would instead look for protection to $\S 943(\mathrm{~b})(7)$, which requires the court to determine that the plan is in the "best interests of creditors and is feasible." This is old language; it was the key test for confirming plans of arrangement under Chapters XI and XII of the Bankruptcy Act $^{175}$ and was also applicable under prior versions of Chapter 9.178 "Feasible" means that the court bellieves that the debtor can fulfill the plan. ${ }^{177}$ "Best interests" is less well-defined. Under Chapters $\mathrm{XI}$ and XII, the term usually referred to the amount that the creditors would receive in a liquidation of the debtor. As the legislative history noted, that could not be the standard under Chapter 9 because municipalities are not liquidated in bankruptcy. ${ }^{178}$

The legislative history points instead toward two pre-Code decisions, Kelley $v$ Everglades Drainage District ${ }^{179}$ and Fano $v$ Newport Heights Irrigation District. ${ }^{180}$ In Fano, an irrigation district had fallen behind on payments on an outstanding bond issue, in part, because the district had undertaken extensive renovations and had paid for them on a current basis. The district sought relief under Chapter IX and sought to reduce the outstanding indebtedness. The district court confirmed the plan, but the appellate court reversed, stating that:

In view of the small amount of deficiency in tax payments shown by the 1937 financial statements of the District, we are unable to find any reason why the tax rate should not have

${ }^{175}$ See 11 USC \$§ 766(2), 872(2) (1976).

${ }^{176}$ Act of August 16, 1937, PL 75-302, 50 Stat 655 c $10 \S 83(\mathrm{e})(1)$.

177 Kane v Johns-Manville, 843 F2d 636, 649 (2d Cir 1988) (whether plan offers reasonable assurance of success); In re Heron, Burchette, Ruckert \& Rothwell, 148 Bankr 660, 684 (Bankr D DC 1992) (same); Sanitary \& Improvement Dist. No. 7, 98 Bankr at 975.

178 The legislative history states that:

The best interest of creditors test does not mean liquidation value as under chapter XI of the Bankruptcy Act. In making such a determination, it is expected that the court will be guided by standards set forth in Kelley v. Everglades Drainage District, 319 U.S. 415 (1943) and Fano v. Newport Heights Irrigation Dist., 114 F. 2d 563 (9th Cir. 1940), as under present law, the bankruptcy court should make such findings as detailed as possible to support a conclusion that this test has been met.

124 Cong Rec 32,403 (Sep 28, 1978) (remarks of Rep Edwards). Finally, paragraph (6) requires that the plan be in the best interest of creditors and feasible. "[In $\S 1129(\mathrm{a})(7)]$, the test is phrased in terms of liquidation of the debtor. Because that is not possible in a municipal case, the test here is phrased in its more traditional form, using the words of art 'best interest of creditors.' " Bankruptcy Law Revision, HR Rep No 95-595, 95th Cong, 1st Sess 400 . (1979).

278 US 415 (1943).

280114 F2d 563 (9th Cir 1940). 
been increased sufficiently to meet the District's obligations or why it can be said that the plan is "equitable" and "fair" and for the "best interest of the creditors" with no sufficient showing that the taxing power was inadequate to raise the taxes to pay them. ${ }^{181}$

In Kelley, the Supreme Court agreed with a bondholder's challenge to a proposed plan of arrangement. The Court held that the fairness of the plan could not be evaluated without specific findings about the extent to which the municipal district could pay the bonds through tax revenues. ${ }^{182}$ The lower court had concluded that the bondholders were "receiving all they [could] reasonably expect under the circumstances,"183 which was then a common reformulation of the best interests test. ${ }^{184}$

Looking to the taxing power of these special districts as the prime source of payment is hardly surprising given the history of creditor's remedies against municipal entities. It would ensure that bondholders effectively receive what they would have received outside of bankruptcy if they were able to obtain mandamus relief requiring an increase in the tax levy. Of course, these cases involved only special districts-a drainage district in Kelley and an irrigation district in Fano ${ }^{\mathbf{1 8 5}}$ _but we see no reason why the same standard should not apply to general-purpose municipalities as well.

As should now be apparent, unsecured creditors of municipalities are protected from the moral hazard problem of opportunistic bankruptcy filings not by the cramdown limit but by the best interests of the creditors standard. Tying that standard to potential tax revenues would put some bite into it. We therefore believe that the interpretation of the best interests standard suggested by the legislative history should be embraced. Even this approach, however, leaves considerable room for judicial discretion and municipal gamesmanship. At a certain point, raising tax rates ceases to raise tax revenues, ${ }^{188}$ but identifying the tax-maximization point on this implicit "Laffer Curve" is not a simple proposition. Presumably

181 Id at $565-66$.

182319 US at $419-21$.

18s Kelley v Everglades Drainage Dist., 132 F2d 742, 744 (9th Cir 1943).

${ }^{184}$ See West Coast Life Ins. Co. $v$ Merced Irrigation District, 114 F9, 655, 678 (9th Cir 1940). See also Lorber $v$ Vista Irrigation District, 127 F2d 628, 639 ( $\left(5 \mathrm{~h}^{2}\right.$ (ir 1942).

${ }^{188}$ Case law under the Bankruptcy Code is extremely limited. In the Matter of Sanitary \& Imp. Dist., No. 7, 98 Bankr 970 (Bankr D Neb 1989) involves yet another special district.

${ }^{186}$ See id at 976. 
city officials are entitled to some deference regarding the probable effects of additional taxation on the community, which means that the moral hazard remains.

4. Collective bargaining agreements and the municipal debtor.

As a matter of political reality, the financial situation of a municipality is often directly related to the city's existing contracts with its employees. Collective bargaining agreements with police officers, firefighters, teachers, garbage collectors, and other municipal employees impose substantial financial burdens on municipalities and are often the apparent source of a municipality's current financial difficulty. Bridgeport, for example, pointed to unaffordable union contracts as a key source of its financial difficulties. ${ }^{187}$ All of this makes the status of those contracts in bankruptcy a matter of some importance.

Section 365 of the Bankruptcy Code deals with executory contracts and empowers the debtor to assume or reject such contracts. Assumption effectively means that the debtor remains liable on the terms of the contract, while rejection more or less constitutes a breach of contract. Under $\S 365(\mathrm{~g})$, the debtor is liable for damages for such a breach, but the liability will be treated as an unsecured claim, and thus is typically not satisfied in full.

There is little reason to distinguish collective bargaining contracts from any other executory contract. Not surprisingly, therefore, the Supreme Court held in NLRB v Bildisco \& Bildisco ${ }^{188}$ that collective bargaining agreements were within the ambit of $\S 365$. Congress, however, responded almost immediately to the Bildisco decision by adding $\S 1113$, which substantially limits the power of the Chapter 11 debtor to reject collective bargaining agreements. Without explanation, and possibly through inadvertence, Congress neglected to make this section applicable to Chapter $9 .{ }^{189}$ Unlike private debtors, therefore, municipal debtors might be able to unilaterally abrogate collective bargaining agreements, subject only to liability for damages for breach of contract. ${ }^{190}$ This

187 See Bridgeport, 129 Bankr at 339.

18s 465 US 513 (1984).

180 The onme iz true of speciel retiree benefit legislation set forth in $\S 1114$ of the Bankruptcy Code. See 11 USC § 901(a).

${ }^{190}$ As others have previously noted. See Schwartz, 66 Am Bankr L J at 120 (1992) (cited in note 151); W. Richard Fossey and John M. Sedor, In re Cooper River School District: Collective Bargaining and Chapter 9 Municipal Bankruptcy, 6 Alaska L Rev 133, 142 (1989). 
result is not wholly without doubt, as Bildisco involved the $\mathrm{Na}$ tional Labor Relations Act rather than state law. In addition, given the special deference paid to state law in Chapter 9 through $\S 903$, state law might be understood to override the power to reject under $\S 365 . .^{191}$ Nonetheless, the apparent freedom to rework pending collective bargaining agreements is one of the principal advantages to proceeding under Chapter $9 .^{192}$ Although there is no reason to believe Congress so intended (other than the bare result), it might be justified on the ground that employee unions, which constitute a significant political interest group in any city, have greater influence with "management" in the municipal than in the private context, and the nonapplicability of $\S 1113$ serves as a counterweight.

\section{The Goals of Municipal Insolvency Law}

We have worked our way from the beginnings of debt collection law for municipalities, through the difficult start of our system of federal municipal bankruptcy, up to the current Chapter 9. In this Section, we consider more generally the appropriate role of a municipal insolvency statute.

We start by considering the more familar justifications for insolvency laws for natural persons and for artificial persons other than municipalities. In each case, we can describe a straightforward principle behind these laws. For natural persons, it is the idea of the fresh start. Individuals who are hopelessly insolvent will not have a stake in their futures. Their efforts will redound almost exclusively to the benefit of their creditors. They will make inefficient investment decisions, as they will be tempted to adopt high-variance projects in a desperate attempt to restore solvency. We could allow individuals to remain in this limbo, having little or no hope for ever extricating themselves from their financial messes. This presumably would have a salutary deterrent effect-assuming that at least some individuals take bankruptcy rules into account when they make decisions. But we have chosen a different path. Perhaps we have run the numbers and have concluded that the losses from a tough policy are exceeded by the gains from a softer

${ }^{101}$ See Barry Winograd, San Jose Revisted: A Proposal for Negotiated Modification of Public Sector Bargaining Agreements Rejected Under Chapter 9 of the Bankruptcy Code, 37 Hastings L J 231, 330-31 (1985): See also Nóte', Municipal Bankruptcy: Will Labor' be Forced to Take the Proverbial Haircut?', $26 \mathrm{Ga}$ L Rev 959, 973 (1992).

${ }_{192}$ Indeed, this was one of the principal reasons that Bridgeport filed for bankriptiptcy. Bridgeport, 129 Bankr at 339. 
approach. Perhaps we believe that individuals do a poor job of making decisions about low-probability events such as bankruptcy, and that these cognitive biases require corrective action by the government. ${ }^{108}$ Whatever the reason, we discharge the debts of the individual, allow him to keep some assets, and permit him to start afresh. ${ }^{194}$

We proceed differently for the failed corporation, partnership, or other state-authorized business entity. We attach no special value to any particular corporate charter, because for a minimal filing fee the state will willingly create a new corporation. We need not worry about discouraging a given corporation from going forward, as the participants in the corporation can home brew a fresh start by incorporating anew. The same is true for partnerships, trusts, and other standard business entities.

Instead, for these entities, our bankruptcy laws should be devoted-and sometimes probably even are devoted-to ensuring that the troubled firm's assets are put to their highest and best use. Sometimes that means liquidating the firm by putting its assets on the auction block. Other times, it may mean downsizing the firm to leave a profitable core. In either case, society as a whole benefits when assets are moved from the failing firm into more effcient uses. Most often when a firm fails, we have learned that the particular combination of physical capital and human capital that the firm represents is a poor match, one that should be reworked. This, of course, is not always true: a bad capital structure will be too much for even an efficient combination of assets, as evidenced by the failed LBOs of the 1980s. But that fact does not change the essential point that bankruptcy should help the failed business firm determine whether the current asset configuration needs to be reworked.

Our bankruptcy laws thus have two central ideas: fresh starts for individuals and a life-and-death decision for the business firm's current mix of assets. Now we come to the municipality: What is the goal of the municipal bankruptcy laws? Although cities are legally classified as municipal corporations, the purposes of federal municipal bankruptcy laws resemble individual bankruptcy more

193 See Jackson, Logic and Limits of Bankruptcy Law 232-41 (cited in note 39).

194 This obviously overstates in that it ignores the entire subject of nondischargeable debts, see 11 USC $\$ 523$, and the power of the court to deny discharge entirely. See 11 USC $\S$ 727; Norwest Bank Nebraska, N.A. v Tueten, 848 F2d 871, 873-76 (8th Cir 1988); In Matter of Bowyer, 916 F2d 1056, 1059-60 (5th Cir 1990), affirmed in reh'g, 932 F2d 1100 (1991). 
than corporate bankruptcy: municipal bankruptcy is based on the idea of the fresh start rather than the efficient reconfiguration of assets. The theory of Chapter 9 is that the burden of debt service, if sufficiently high, will affect the taxpayers of a city as it would a debt-ridden individual: it will sap initiative and depress moneygenerating activity. The debt-ridden individual will cease to work if all the gains go to the creditor; the taxpayers of a city will cease to pay taxes if rates are too high and the citizens get none of the benefit. In both contexts, bankruptcy is premised on the idea that the debtor will become more productive if freed from the burden of debt, but the law presumes that the debtor will survive bankruptcy in essentially the same form that it went in. We do not dismember individuals the way we do private corporations that file for bankruptcy - that is hardly surprising-but what may be surprising is that we do not dismember municipal corporations either.

Would it not be possible to construct a municipal bankruptcy regime with the goal of forcing more efficient forms of municipal organization? In the case of business corporations, we readily recognize that the entity's size and scope of operations can be changed, and even that the corporation can be liquidated altogether. Is it not equally true that a municipal corporation's size and scope of operations could be changed? And that bankruptcy signals the need for fundamental reform of the city's structure and affairs?

Under the present municipal bankruptcy regime, bankruptcy serves no such function. Indeed, it serves little function at all. Between 1938 and 1972, 362 municipal bankruptcy cases were filed. ${ }^{195}$ Of that number, 343 , or nearly ninety-five percent of the total, were filed before 1952. ${ }^{196}$ From 1972 through the end of 1991, there were an additional ninety Chapter 9 filings, for a total of 452 filings as of that date over the entire history of the statute. ${ }^{197}$ If we focus on general municipalities (excluding special purpose districts, which are the large majority of insolvent municipal debtors), the number of cases is even smaller. There were only three Chapter 9 filings by general municipalities between 1972 and 1984, and none of these was related to the long-term financial health of the city. These are Chapter 9's Texacos, Manvilles and A.H. Robins. A youth jumps off of a municipal pier in Bay St. Louis, Mississippi,

108 George H. Hempel, An Evaluation of Municipal "Bankruptcy" Laws and Procedures, 28 J Fin 1339, 1342 (1973).

${ }^{108} \mathrm{Id}$.

${ }^{197}$ Municipal Bankruptcy Risk, Global Guaranty 1 (Dec 16, 1991). 
and breaks his neck. The city suffers a $\$ 370,000$ judgment and files under Chapter 9 to prevent garnishment of its bank accounts. ${ }^{198} \mathrm{~A}$ South Tucson, Arizona police officer shoots and paralyzes a fellow officer during an incident. The injured officer wins a $\$ 3.6$ million judgment against the city. Eventually this city too files under Chapter 9. ${ }^{199}$ In Wapanucka, Oklahoma, a complicated chain of events spells disaster: an oil tanker crashes and thereby fouls the town's water supply. A lawsuit is commenced to recover, but in the meantime, the town needs water-the town condemns a local well, expecting to pay a modest $\$ 5,000$, but a court instead awards $\$ 112,000$. The town files under Chapter 9 to gain time to prevent execution of the condemnation award while pursuing its lawsuit against the oil company. ${ }^{200}$ More bankruptcies of this sort may be expected, given the potential liability municipalities face under CERCLA. ${ }^{201}$ But these instances do not signal any need for corporate reorganization.

More to the point is the abortive bankruptcy attempt of Bridgeport, Connecticut, an unfortunately not atypical city with a declining tax base, an impoverished citizenry, multiplying needs and chronically insufficient revenue. Bridgeport was not permitted to file for bankruptcy, essentially because it was still able to live off credit, but the end is in sight. Bridgeport and countless cities like it appear to be in grave need of reorganization. Can bankruptcy law help? More specifically, if we abandon our presupposition that municipal corporate structures and boundaries are inviolable and that the process of bankruptcy should not be allowed to affect the "political" decisions of city managers, would a more efficient municipal structure emerge? As will become evident, this inquiry requires us to confront the most basic issue of municipal government law: what are cities for? This Section will explore the possibility of alternative municipal bankruptcy regimes. ${ }^{202}$

${ }^{108}$ See ACIR, Bankruptcies (1985) at 8, 10 (cited in note 158).

${ }^{190}$ Id at 11.

200 Id at 10-11.

${ }^{202}$ Comprehensive Environmental Response, Compensation, and Liability Act of 1980, 42 USC $\S \S 9601-9675$ (1988 \& Supp 1991).

${ }^{202}$ This section is concerned solely with general purpose municipalities. Most municipal bankruptcies involve special purpose districts rather than general purpose municipalities, but special districts more closely resemble ordinary corporations and present less interesting problems for municipal bankruptcy. 
A. Expanding the Powers of the Bankruptcy Court

Current municipal bankruptcy law strictly limits the powers-hence the utility-of the bankruptcy court. Chapter 9 expressly prohibits the bankruptcy court from interfering with the "political or governmental powers of the debtor." As discussed above, this perpetuates the old common law doctrine that forbade the courts from ordering cities to reduce expenditures and thus gave current spending decisions absolute priority over past debts, as well as the doctrine protecting all public property-or at least that devoted to a "public use," which is almost all public property-from attachment and seizure. Presumably, it also precludes the bankrupcy court from exercising the principal common law judicial remedy for nonpayment of debts-the order to raise taxes. All these involve "political or governmental powers" and are outside the authority of the Chapter 9 court, at least in theory.

But there would be significant advantages to relaxing these constraints. In most cases, ${ }^{203}$ chronic financial difficulty is a sign that ordinary political processes are not functioning properly. Bankruptcy could be used to force politically unpopular, but sensible, decisions such as elimination of municipal functions, privatization, and changes in tax law. Chapter 9, as drafted, attempts to prevent the bankruptcy courts from performing any such function. But to continue past practices may guarantee continued financial distress in the future. For example, it was widely thought that a principal reason why Cleveland was in such serious financial difficulties in the mid-1970s was its inefficient and uneconomic operation of a municipal power company. ${ }^{204}$ Similarly, an outsized city payroll and generous public services (such as free tuition at City University of New York) were among New York City's major financial problems. ${ }^{205}$ Merely to give the city a fresh start, but not to address the fundamental causes of its financial problems, may be no favor. To be sure, bankruptcy would displace democratic decisionmaking. But if democratic decisionmaking has proven incapa-

${ }^{203}$ Exceptions are the tort-driven bankruptcies discussed above at text accompanying notes 198-201. Moreover, in some instances, the fault lies not with the political decisionmakers, but with the political boundaries, an issue we explore below.

${ }^{204}$ See, for example, City Defaults on Notes, Facts on File World News Digest at 1008 G1 (Dec 31, 1978).

${ }^{205}$ See David Alpern, et al, New York's Last Gasp?, Newsweek 18 (Aug 4, 1975). For an examination of New York City's current budgetary woes, see Edwin S. Rubenstein, A Citizen's Guide to City Government, City J 26 (Spring 1993). 
ble of making ends meet, that could be viewed as an advantage of bankruptcy-not something to be avoided.

Receivers appointed under state law have had notable success in disciplining municipal budgets and restoring financially distressed cities to solvency. Ecorse, Michigan, for example, went into court-ordered receivership in December, 1986, after years of unbalanced budgets and an accumulation of $\$ 6$ million in unpaid debts. Ecorse, a city of 12,000 downriver of Detroit, was a prosperous industrial center in the $1950 \mathrm{~s}$, but had lost almost all of its industry and forty percent of its population by the mid-1980s. The receiver privatized most municipal services (including snow removal, tree trimming, debris removal, weed cutting, street sweeping, water and sewer maintenance, and street, alley, and sidewalk repairs), closed underused facilities (including libraries and an ice rink), cut the payroll, and sold the building and equipment of the Department of Public Works. In just three years he halved the annual budget, eliminated the deficit, and paid off all but $\$ 1$ million of the debt. ${ }^{208}$ It was not an exercise in democracy-but ordinary political processes had failed to do what was necessary.

Better known (though perhaps less successful in the long run) was the rescue of New York City from default in 1976-1977, largely through transferral of fiscal authority to a state-appointed Emergency Financial Control Board with power to set city expenditure levels, contracts, and budget. ${ }^{207}$ Pennsylvania has an extensive state scheme for financially-distressed municipalities. ${ }^{208}$ Scranton, Pennsylvania's fifth largest city, with a population of 81,000 , invoked the protection of this act in $1991 .{ }^{209}$ In 1991, Chelsea, Massachusetts, a city of 28,000 , was put into receivership pursuant to special state legislation. ${ }^{210}$ In other cases, special state oversight

208 Ted Hampton, Receivership Can Be Powerful Tool for Righting Fiscal Wrongs, Former Ecorse, Mich., Czar Says, The Bond Buyer 28 (Feb 7, 1992); Larry Green, Michigan Bond Expert Assumes Task; City Takes Debt Medicine: Loses Its Power to Govern, LA Times A12 (Jun 24, 1989); Greg Kaza, A Town Gets Rid of Its Deficit-And Most of Its Government, Newsday 87 (Dec 15, 1989).

${ }^{207}$ For a description of state efforts to avert default, see Flushing National Bank $v$ Municipal Assistance Corp., 358 NE2d 848, 859-60, 40 NY2d 731 (1976) (Cooke dissenting). See also Alpern, et al, Newsweek 18 (cited in note 205); Donna E. Shalala and Carol Bellamy, A State Saves a City: The New York Case, 1976 Duke L J 1119.

${ }^{208}$ Financially Distressed Municipalities Act, $53 \mathrm{~Pa}$ Cons Stat Ann $\S 11701.101$ et seq.

See Emmet, Fiscal Distress (cited in note 168), for a review of the law.

${ }^{200}$ See Michael deCourcy Hinds, A Campaign to Pull Scranton Back from Disaster, NY Times A12 (Jul 21, 1992), for a description of the Scranton experience.

210 See Powers v Secretary of Administration, 412 Mass 119, 587 NE2d 744, 745 (1992). See also Brian McGrory, Carlin Leaves a Solvent Chelsea, but More Tasks Remain, Boston Globe 20 (Jul 31, 1992). 
boards are created to oversee a municipality's finances. Operating power remains with elected officials. Three cities in Massachusetts-Brockton, Lawrence, and Lowell-are currently operating in this manner. 211

Federal bankruptcy courts have been explicitly denied any such powers. But in practice, the bankruptcy court may have more authority than at first appears. To be sure, the court may not order reductions in expenditure, sale of property, renegotiation of contracts, or increase in taxes. But the court can refuse to accept the city's debt adjustment plan on the ground that it is not in the "best interests of the creditors." This provision could be interpreted to mean that the city is capable of taking steps that would be more advantageous to the creditors than defaulting, ${ }^{212}$ and in most instances this probably means cutting spending, selling property, or raising taxes. Either of the first two interpretations would represent a stretch-at least as measured by the cases cited in the relevant legislative history ${ }^{213}$-but ordering the levy of previously authorized taxes would not. That might be a sufficient club to lead to judicial control by a wink and a nod, as the city determines what it must do-_voluntarily"-in order to induce the court to accept a plan of adjustment.

There is precedent for this kind of judicial activity under Chapter 11, under which the bankruptcy court is barred from modifying a plan. In practice, this means that the creditors must determine the judge's objections to a proposed plan and alter it accordingly. The effect may be to alter the balance of power somewhat, but probably not to affect the bottom line to any substantial degree. In much the same way, even under Chapter 9 an aggressive court could presumably insist upon various steps involving the "political or governmental powers of the debtor" as the price of approval of a plan. Thus, the bankruptcy court's authority could be greater than it seems.

There are, however, three reasons to believe current bankruptcy powers are inadequate under this vision of the purposes of bankruptcy. First, the "best interests of the creditors" standard might not be intended to give the court such broad discretion to second-guess the city's financial arrangements. As discussed above, "best interest of the creditors" was borrowed from private bank-

211 See Michael Grunwald, Renewal of Fiscal Board is Weighed; Progress by Brockton is Noted, Boston Globe 1 (Mar 14, 1993).

${ }^{212}$ For more complete discussion of this provision, see Section II.B.3.

${ }^{213}$ See text accompanying notes 178-86. 
ruptcy law, where it means, roughly, that creditors should not be worse off in bankruptcy than they would be out of bankruptcy. The legislative history pointed to two cases in which the courts explored whether tax levels were sufficient-which is consistent with the general standard, since the mandamus to raise taxes was the creditors' principal remedy outside of bankruptcy. The question is whether this concept could be broadened to encompass other municipal financial measures that could improve the creditors' chances of payment, but that are beyond the judicial power under the common law.

Second, even if the bankruptcy court has authority to engage in this kind of decisionmaking, implementation of the "deal" would require action by the city's political leadership. If, for example, the court agreed to accept the city's proposed plan of adjustment only if it privatized a costly city-owned utility, it would then be necessary for the city council to approve the privatization scheme. Since the political leadership had not been able to take such steps on its own, it is doubtful that it would do so now. ${ }^{214}$ Thus, even if a rational city administration would agree to the court's proposals, the same failed administration that created the financial crisis would likely fail to agree to the steps to solve it. The only hope is that the politicians could shift the "blame" to the court, and thus break the political log jam. Failing this, however, coercive authority is likely to be necessary.

Third, even if the bankruptcy court has the requisite authority and the political process is fully rational and cooperative, it may be that the city lacks the legal authority to make all the reforms that may be necessary. Thus, one way to use bankruptcy more constructively would be for Congress to expand the powers of the court to enable it to order politically unpopular reforms. This would require not only a radical revision in the theory of Chapter 9 , but also reconsideration of some of the basic common law principles of municipal debt collection.

Of the six creditors' remedies discussed in Section I, four should be permitted to the bankruptcy court. First, the power to order the levying and collection of taxes authorized at the time of

214 Often, municipal financial crisis is accompanied by political paralysis. See, for example, Bill Peterson, Cleveland: City Where Politics Has Failed, Wash Post A3 (Dec 28, 1978) ("This is a city where politics has failed, where the normal give-and-take of compromise has turned into a theater of the absurd."); Alpern, et al, Newsweek 18 (cited in note 205) ("There was no question that New York's problems were largely due to the expansiveness, ineptitude and plain irresponsibility of its leaders."). 
the creation of a consensual debt-the recognized mandamus remedy-should be vested in the bankruptcy court, so that a single tribunal can deal with the entire range of issues arising from the municipal debt structure. This would merely make explicit through the statute that the bankruptcy court can exercise the authority over state and local taxes that federal courts traditionally have exercised outside of bankruptcy. A bankruptcy court might also be empowered to increase taxes even without a prior state authorization, but this would likely be held unconstitutional, and should be. ${ }^{215}$ Second, in derogation of common law doctrine, the bankruptcy court should be able to order reductions in wasteful expenditures as a condition for debt relief. The absolute priority of current spending decisions over debt repayment is part of the problem, and removing it would be part of the solution. This power would parallel that given to state receivers for municipalities under applicable state law. And third, the ability to attach particular streams of income for the repayment of bonds-subject, of course, to prior pledges of these revenue streams-can enable the city to obtain more favorable terms for refinancing. During New York's debt crisis, the Municipal Assistance Corporation, the state agency created for restructing the city's debt, was assigned first claim to the city's sales and stock transfer taxes and all its per capita state aid. This undoubtedly enabled the agency to fund the debt more cheaply, and thus to resolve the financial crisis at lower cost.

Perhaps more importantly, the court should be empowered to sell municipal property in appropriate instances. Allowing a city to keep all of its assets while being discharged of its debts is the principal source of the moral hazard problem in municipal bankruptcy. There are persuasive reasons to protect true public trust property-for example, streets and alleys, central parks, and beaches.

215 The concurring opinion in Missouri $v$ Jenkins carefully distinguished those cases in which mandamus was issued to enforce preexisting taxing authority from cases such as United States $v$ County of Macon, 99 US 582, 590-91 (1879), in which no preexisting authority existed. 495 US at 71-71 (Kennedy concurring). The majority opinion held otherwise for the purpose of remedying desegregation, see Jenkins, 495 US at 56-57, but probably did not reach the issue for general tax increases to pay debts. The majority cited only Van Hoffman $v$ City of Quincy, 71 US 535 (1866), in which the Court issued mandamus based on the taxing authority that existed at the time of the issuance of the bonds. The state had limited that taxing authority after the fact, and the Court found the new limit to contravene the Contracts Clause. 71 US at 554-55, cited in Jenkins, 495 US at 56-57. Van Hoffman therefore is just a straightforward application of the Contracts Clause, and no more. The Jenkins majority opinion is an unpersuasive reading of both precedent and principle, and is probably explicable only on the basis of its particular political context. 
Such property is not merely devoted to a public use (an expansive concept) but has properly been deemed inalienable under common law. ${ }^{216}$ Public trust property is property used to provide a genuine public good; social welfare would be diminished if it passed into private hands. To put the point in economic terms: any property that generates positive externalities that cannot be captured by the owner and that exceed the private value of the land should be left in public control. In addition, there may be other municipal property-not within the traditional boundaries of "public trust" property-whose value in city hands so far exceeds its value to private purchasers that its seizure and sale should be barred. But there is no persuasive reason to deny the bankruptcy court the power to require the city to sell other valuable property, such as land acquired for nonpayment of taxes, ordinary equipment or office space, municipally-owned profit-making businesses, or bank accounts. ${ }^{217}$ Indeed, one of the most important strategies for restoring fiscal health is the privatization of previously governmental services. This can both generate cash and reduce operating inefficiencies and subsidies. But it cannot be done through bankruptcy if all governmental property is exempt from sale. Thus, by narrowing the gap between the rights of municipal and private creditors, the bankruptcy court could be enabled to provide genuine and needed fiscal discipline, rather than just to discharge the debts and return the city to its former ways.

Moreover, if filing for bankruptcy entailed a grant of jurisdiction to the court over basic spending, taxing, and property decisions, it would no longer be necessary to have restrictive gatekeeper provisions, like the insolvency requirement, that delay bankruptcy to the detriment of both creditor and debtor. ${ }^{218}$ Those restrictions are a response to the moral hazard of easy debt relief, coupled with the insulation of municipal property from seizure and sale. If the powers of the bankruptcy court were expanded as suggested, there is little danger that political leaders would file precipitously, or that they would behave irresponsibly beforehand in reliance on easy debt relief. By making the consequences of

${ }^{218}$ See Illinois Central Railroad v Illinois, 146 US 387, 452-62 (1892); Richard A. Epstein, The Public Trust Doctrine, 7 Cato J 411 (1987).

${ }^{21 z}$ To stave off default, the City of Cleveland sold off its parks, zoo, sewer and transit systems, and stadium operations. Peterson, Wash Post at A3 (cited in note 214).

${ }^{218}$ See text accompanying notes 134-39. Similarly, the "good faith" requirement would have little significance. 
bankruptcy for the city more severe, it becomes possible to make it more readily available to distressed municipalities. ${ }^{219}$

If bankruptcy courts were converted into an instrument of long-term reform of municipal finances along lines more similar to private bankruptcy, the question arises whether-as in private bankruptcy-creditors should be permitted to file a petition and force the debtor into involuntary bankruptcy. If the city's fiscal troubles are caused, in part, by irresponsible political management, then creditors could perform a useful function as monitors and instigators of outside intervention. On the other hand, involuntary bankruptcy would pose serious constitutional difficulties.

Under a system of expanded bankruptcy powers, even voluntary bankruptcy - that is, a regime in which the city has the right, but not the obligation, to petition for bankruptcy-would allow the federal court to trench deeply into the internal political processes of state and local governments, and thus may be unconstitutional. These problems might be solved simply by retaining the feature of present law allowing states to choose whether to allow their municipalities to file for bankruptcy. But this is not obvious. States may not be able to waive fundamental aspects of their own autonomy. The precise extent of federalism protection under the Constitution today is in doubt, but a good argument can be made that for a federal bankruptcy court to assume municipal powers of taxation, property disposition, and spending-even with state authorization-would be going too far. ${ }^{220}$

Involuntary bankruptcy would be even more problematic. If the state required the city to file (either by general legislation or case-specific order) the constitutional situation would be no different, from the point of view of federalism, than if the city chose to file. But if the state left the matter to municipal discretion, under

210 Allowing sales of municipal property inside of bankruptcy but not outside of bankruptcy might be thought to create a forum-shopping problem: distressed situations which might be worked out outside of bankruptcy will now be filed to gain access to the new sale power. So long as the current bar against involuntary filings is maintained, this should not pose a substantial problem. Creditors cannot move the case into bankruptcy directly, and, given the inability to seize assets outside of bankruptcy, they probably cannot coerce a filing. The city itself, of course, can sell outside of bankruptcy and so would not need to file to be able to sell assets.

${ }^{220}$ If we assume that it would violate the Constitution for the federal courts to assume these powers coercively, then it might well be a violation, under the unconstitutional conditions doctrine, for the federal courts to withhold the substantial benefit of allowing debt adjustment unless the states and cities waived their constitutional rights in this regard. See generally Richard A. Epstein, The Supreme Court 1987-Foreword: Unconstitutional Conditions, State Power, and the Limits of Consent, 102 Harv L Rev 4 (1988); Kathleen Sullivan, Unconstitutional Conditions, 102 Harv L Rev 1415 (1989). 
home rule power or otherwise, involuntary bankruptcy could take place without either level of government affirmatively sanctioning it. It would be a raw exercise of federal power-in effect, refusing to give effect to the state's decision to leave the bankruptcy decision in the hands of the city. ${ }^{221}$

It may well be, therefore, that federal municipal bankruptcy law is even more fundamentally misconceived than at first appeared: there shouldn't be any. If we need municipal bankruptcy courts with far-reaching powers, but such courts would be inconsistent with our federal system, it follows that states and not Congress should establish them. Indeed, many states-like Ecorse's Michigan-have done just that. An additional reason to favor state bankruptcy law is that state resources could be employed as part of the package. Under many state plans, for example, the state will lend its credit to a distressed municipality-provided the city agrees to specified fiscal reforms-thus enabling the city to refinance its outstanding obligations at a far lower interest rate. States also have the power to make changes in municipal governance or municipal boundaries that may be a useful part of reorganization. Under the current system, in which federal bankruptcy is an alternative to state reform rather than supplemental to it, ${ }^{222}$ no one is in a position to coordinate state assistance to federal debt adjustment. We therefore recommend that the states be empowered to displace federal municipal bankruptcy law with state municipal bankruptcy law.

Does this proposal return to the other horn of the old constitutional dilemma: that the Contracts Clause prohibits states from passing effective bankruptcy laws? We think not. First, the Supreme Court rejected that argument in Faitoute, ${ }^{223}$ which appears

221 Since the municipal bankruptcy statute applies specifically to cities and not to private entities, it is subject to judicial scrutiny under New York v United States, $112 \mathrm{~S} \cdot \mathrm{Ct}$ 2408 (1992), rather than Garcia $v$ San Antonio Metropolitan Transit Authority, 469 US 528 (1985). Under traditional principles, the "number, nature and duration of the powers conferred upon [municipal corporations] rests in the absolute discretion of the State." Hunter $v$ City of Pittsburgh, 207 US 161, 178 (1907). To allow involuntary bankruptcy in the absence of affirmative state authorization would effectively prohibit states from delegating this decision to their cities, and thus run afoul of Hunter. It might be argued that this is permissible under Lawrence County o Lead-Deadwood School Dist. No. 40-1, 469 US 256 (1985) (upholding federal statute requiring states to delegate discretion over spending certain federal monies to the municipalities that receive them), but this case, even if correctly decided, rests upon the view that Congress has authority to impose conditions on its expenditure of funds. Id at 269-70. Such a principle, if extended to other federal powers, would swallow up federalism principles.

222 See text accompanying notes 140-55.

213316 US at 509-16; see text accompanying notes 122-24. 
still to be good law. Faitoute stands for the proposition that the Contracts Clause is not violated if-as a practical and not a technical matter-the state substitutes a remedy that is as valuable as the one that had been contracted for. In effect, the Contracts Clause allows state municipal bankruptcy laws but constitutionalizes a "best interest of the creditors" test, ${ }^{224}$ preventing the states from adopting debt adjustment programs that benefit the municipal debtor at the expense of the creditors. ${ }^{225}$

Second, in Faitoute, New Jersey added the state insolvency legislation after the bonds had been created and it was that feature which raised an impairment problem. The Contracts Clause itself does not bar a before-the-fact state insolvency scheme, as it would be incorporated into the contract. ${ }^{228}$

Third, even if it were true that the Contracts Clause bars any state from imposing involuntary debt adjustments, there is no reason Congress could not substitute for Chapter 9 framework legislation that uses the federal power to abrogate contracts solely as an adjunct to state-ordered plans under state law. The only legal bar, ironically, is the Bankruptcy Code itself, which prevents states from ordering debt adjustment plans, ${ }^{227}$ undoing the states' victory in Faitoute. It seems to us that the reverse is more desirable: state bankruptcy law is both more consistent with our constitutional structure and more likely to be effective on the merits than federal bankruptcy law.

One might object that states would choose not to enact adequate municipal bankruptcy laws. That is always a risk when decisions are decentralized. But states have a strong incentive (stronger than the federal government) to protect and strengthen the financial stability of their cities. A municipal default of one city will have a serious impact on the rest of the state. We have no reason to believe that states would be recalcitrant. The lack of state municipal bankruptcy laws prior to the federal act does not

224 See id at 514 (describing the state debt adjustment statute as being "for the protection not only of their credit [i.e., the credit of the municipalities] but of all the creditors").

${ }^{225}$ In addition to Faitoute, see United States Trust Co. $v$ New Jersey, 431 US 1, 28 (1977). A more difficult question is how to reconcile state municipal bankruptcy relief with state constitutional requirements of full faith and credit. Such a requirement proved to be an impediment to the program to avert default by New York City in 1976. See Flushing National Bank v Municipal Assistance Corp., 358 NE2d 848, 40 NY2d 731 (1976).

${ }_{226}$ Ogden $v$ Saunders, 25 US (12 Wheat) 213 (1827).

227 See 11 USC $\$ 903$. 
prove that states were unwilling, but only that they were then thought to be barred by the Contracts Clause. ${ }^{228}$

\section{B. Dissolution of the Municipal Corporation}

The previous discussion assumes that the city will survive bankruptcy, albeit in altered form. But to press more rigorously the analogy to private bankruptcy, we must ask whether the very corporate structure-the independent existence-of the bankrupt city should be reconsidered. Cities may appear fixed and permanent, but they are purely a creation of law and thus subject to legal revision. Indeed, the physical boundaries of municipal entities change with surprising frequency. In the ten-year span from 19701979, there were 61,356 annexations to municipalities and 1,026 detachments. ${ }^{228}$ As these figures indicate, cities often expand and, less frequently, cities divide.

Municipal corporations can also be liquidated. Unlike a state or (in most state constitutional systems) a county, a city or a special district can cease to exist, and the territory can be governed as an unincorporated part of the county. Between 1942 and 1972, the number of governmental units declined by nearly half, many of them through merger with other units of government but some through simple disincorporation. ${ }^{230}$ Between 1960 and 1970, 184

228 It would also be possible (though not necessarily desirable) to retain a federal system for cities in states that have not adopted a state system.

229 See US Dept of Commerce, Bureau of the Census, Boundary and Annexation Survey, 1970-79 2 (GPO, 1980).

2s0 The biggest single source of decline relates to the dramatic drop in the number of school districts from 108,579 in 1942 to just 15,781 in 1972. There has been a steady decline in the number of townships and towns, though if you instead focus on the total number of municipalities, townships and towns, there is a one-time drop from 35,139 in 1942 to 34,009 in 1952, with a steady rise thereafter. The following chart sumarizes the evidence:

\begin{tabular}{|llllllllll|}
\hline Type of Government & 1942 & 1952 & 1957 & 1962 & 1967 & 1972 & 1977 & 1982 & 1987 \\
Total & 155,116 & 116,807 & 102,392 & 91,237 & 81,299 & 78,269 & 79,913 & 81,831 & 83,237 \\
U.S. Government & 1 & 1 & 1 & 1 & 1 & 1 & 1 & 1 & 1 \\
State Government & 48 & 50 & 50 & 50 & 50 & 50 & 50 & 50 & 50 \\
Local Government & 155,067 & 116,756 & 102,341 & 91,186 & 81,248 & 78,218 & 79,862 & 81,780 & 83,186 \\
County & 3,050 & 3,052 & 3,050 & 3,043 & 3,049 & 3,044 & 3,042 & 3,041 & 3,042 \\
Municipal & 16,220 & 16,807 & 17,215 & 18,000 & 18,048 & 18,517 & 18,862 & 19,076 & 19,200 \\
Township \& Town & 18,919 & 17,202 & 17,198 & 17,142 & 17,105 & 16,991 & 16,822 & 16,734 & 16,691 \\
School District & 108,579 & 67,355 & 50,454 & 34,678 & 21,782 & 15,781 & 15,174 & 14,851 & 14,721 \\
Special District & 8,299 & 12,340 & 14,424 & 18,323 & 21,264 & 23,885 & 25,962 & 28,078 & 29,532 \\
\hline
\end{tabular}

Adjusted to include units in Alaska and Hawaii which adopted statehood in 1959.

US Dept of Commerce, Bureau of the Census, Statistical Abstract of the United States: 1990272 (GPO, 110th ed 1990). 
municipalities, mostly rural communities, disincorporated. ${ }^{231}$ To be sure, many of these were little will-o'-the-wisp towns of a dozen or so folks, but these towns didn't start that way, and for them, disincorporation represents the end of an often long decline. ${ }^{232}$ Others were areas that decided to try local general government, only to conclude very quickly that prior arrangements served them better. ${ }^{233}$ Still others were shut by disasters, natural or man-made. ${ }^{234}$ Cities, as legal entities, are not a necessary feature of the landscape; they are optional. A map of the Chicago metropolitan area shows much unincorporated territory. Iowa has one unincorporated town for every four incorporated towns. ${ }^{235}$ In other states, unincorporated towns have populations numbering in the tens of thousands. ${ }^{236}$ There is no legal reason why a municipal corporation cannot simply liquidate and cease to exist.

In the private context, bankruptcy serves to induce corporate reorganizations-of size, scope, and even of existence-to produce more efficient configurations. ${ }^{237}$ That an entity files for bankruptcy is prima facie evidence (though not dispositive proof) of a defect in the present corporate design. Perhaps the same could be said of municipal bankruptcy. As Richard Briffault has observed, "there may be no neutral, 'scientific' answer concerning the optimal struc-

291 Bill Richards, The Two Faces of the American Heartland, Wash Post A1 (Dec 21, 1977) (citing figures compiled by Stanley V. Voelker of the US Agriculture Department's Economic Research Service).

${ }^{232}$ Tiny Town Wipes Itself Off the Map, Wash Times B8 (Jan 9, 1991) (describing 6-1 vote in favor of disincorporating by town of Donnon, Iowa); UPI, (untitled item) (Dec 29, 1983) (available in LEXIS NEXIS/UPSTAT database) (describing 20-0 vote in favor of disincorporating by city of Yost, Utah).

${ }^{233}$ Pine Valley, New York incorporated in March, 1988, and voted to disincorporate barely two years later. See Steve Wick, Auditors Criticize Village, Newsday 20 (Apr 19, 1990). Liberty City, Texas incorporated and disincorporated within the space of three years. UPI (untitled item) (Apr 9, 1982) (available in LEXIS NEXIS/UPSTAT database).

${ }^{234}$ Times Beach, Missouri, best known as the site of a major dioxin contamination, disincorporated in early 1985 . The town's population had dwindled from 2,242 prior to knowledge of the disaster to 2. See By Governor's Order, Times Beach is Gone, Chi Trib 3 (Apr 4, 1985).

${ }^{235}$ After the disincorporation of Plain View, Iowa, the number of incorporated Iowa towns was 955, but according to the Iowa League of Muncipalities, there were between 250 and 270 unincoporated towns. UPI (untitled item) (Mar 3, 1987) (available in LEXIS NEXIS/UPSTAT database).

${ }^{238}$ For example, the unincorporated area known as Channelview, outside of Houston, has a population of 17,000 , while unincorporated Rio Grande City has a population of about 10,000. UPI (untitled item) (Jul 30, 1985) (available in LEXIS NEXIS/UPSTAT database).

${ }^{237}$ At least that is the hope. The academic literature is largely critical of Chapter 11. See Michael Bradley and Michael Rosenzweig, The Untenable Case for Chapter 11, 101 Yale L J 1043 (1992); Douglas G. Baird, The Uneasy Case for Corporate Reorganizations, 15 J Legal Stud 127 (1986). 
ture for metropolitan governance: different structures will favor or harm different interests."298 When a municipality cannot make ends meet, this might indicate that a more fundamental change needs to be made-something more than just a conventionally understood fresh start.

When a private corporation is liquidated in bankruptcy, it can simply cease to exist. Its assets are distributed, and there is nothing left to it. The same might be true of many special districts, which make up the vast majority of municipal bankruptcies. ${ }^{239}$ Liquidation of a general municipal corporation, however, is more complicated. Cities exercise a portion of the state's police power and perform certain essential services, neither of which can simply cease. Moreover, cities own property that may constitute a quintessential public good, and which should not be allowed to devolve into private hands. We must therefore consider: if a city is dissolved, what becomes of its residual powers and obligations?

The answer to that question depends on one's theory of the nature of municipal government. There are two principal theories. ${ }^{240}$ Under one, associated with the great treatise writer and Iowa Supreme Court Justice John Dillon, cities are nothing more than instrumentalities of the state, created by the state for the more effective implementation of state policies. It would seem to follow, under this theory, that if the municipal corporation is dissolved, its powers and obligations revert to their source, the state, or perhaps to a parallel or intermediate level of government designated by the state, such as a neighboring jurisdiction or the county. The competing theory, associated with Michigan Supreme Court Justice and constitutional treatise writer Thomas Cooley, holds that cities are the creations of their citizens, for their own purposes, exercising a fundamental right of self-government. Under this theory, it would seem to follow that if the municipal corporation is dissolved, the citizens are free to exercise their primordial right to form others, which would exercise like powers and be subject to like obligations. As we shall see, these two views have very different implications for liquidation in bankruptcy.

\footnotetext{
$2 s$ Richard Briffault, Voting Rights, Home Rule, and Metropolitan Governance: The Secession of Staten Island as a Case Study in the Dilemmas of Local Self-Determination, 92 Colum L Rev 775, 779 (1992) (footnote omitted).

2s0 See text accompanying notes 193-202.

210 For a useful summary of the two theories, see Joan C. Williams, The Constitutional Vulnerability of American Local Government: The Politics of City Status in American Law, 1986 Wis L Rev 83, 88-100, 137-49.
} 


\section{Merger and Consolidation}

The Supreme Court has long held that our Constitution "looks to an indestructible Union, composed of indestructible states."241 Moreover, most states divide the entire territory among counties, which perform essential services such as the provision of roads, courts, tax assessment, and sheriffs' departments. While counties are not indestructible - they may be merged or redivided or their boundaries redrawn by the state-each square inch of the state at every moment is part of one and only one county. ${ }^{242}$ According to traditional theory, however, cities and villages, unlike counties or states, are a quasi-voluntary form of organization, created at the instigation of the local citizens for the purpose of joint provision of a wider range of municipal services than are available from the county or the state. ${ }^{243}$

Areas not within a city, town, or other municipal government are left unincorporated, subject only to the governance of the county and the state. Unincorporated areas typically get by on lower taxes and lower services, and the presence of incorporated as well as unincorporated areas provide citizens in the metropolitan area a choice of the mix of taxes and services they desire.

241 Texas $v$ White, 74 US (7 Wall) 700, 725 (1868).

${ }^{242}$ This is not true of every state. In Virginia, for example, territory within a first class city is withdrawn from the county, and Connecticut, Rhode Island, and Alaska lack organized county government (though boroughs perform much the role of counties in inhabited parts of Alaska). In Louisiana, counties are termed "parishes." Moreover, in some places (Philadelphia, Indianapolis, San Francisco, and Nashville, for example), city and county government have merged, while in others (New York, for example), the city is larger than the counties. In these exceptional circumstances, the framework described in the text would not apply.

${ }^{243}$ See Hamilton County Commissioners v Mighels, 7 Ohio St 109, 118-19 (1857):

[M] unicipal corporations proper are called into existence, either at the direct solicitation or by the free consent of the people who compose them.

Counties are local subdivisions of the state, created by the sovereign power of the state, of its own sovereign will, without the particular solicitation, consent, or concurrent action of the people who inhabit them. The former organization is asked for, or at least asssented to by the people it embraces; the latter is superimposed by a sovereign and paramount authority.

A municipal corporation proper is created mainly for the interest, advantage, and convenience of the locality and its people; a county organization is created almost exclusively with a view to the policy of the state at large, for purposes of political organization and civil administration, in matters of finance, of education, of provision for the poor, of military organization, of the means of travel and transport, and especially for the general administration of justice. With scarcely an exception, all the powers and functions of the county organization have a direct and exclusive reference to the general policy of the state and are, in fact, but a branch of the general administration of that policy. 
In the event of dissolution, some states might choose to merge the dissolved city into surrounding jurisdictions. The advantage would be to broaden the tax base and achieve economies of scale, though there is some danger that the debt-ridden city would drag down its stable neighbor. There is precedent for merger in the case of special districts, and especially school districts, ${ }^{244}$ and Michigan legislators considered enactment of a formal mechanism for merging financially distressed cities in the wake of the Ecorse receivership. Successful though the receivership was in bringing the budget under control, the receiver was quoted as stating that "Ecorse ought to disappear."245

More likely, if the municipal corporation dissolves, governing responsibility could devolve upon the county. This would have two effects. First, it would eliminate all municipal services in the formerly incorporated part of the county that were above and beyond those provided in the unincorporated part. This should be a rough proxy for essential governmental services, at least in theory. ${ }^{246}$ Second, it would shift the costs of providing those essential services from the citizens of the former city to all the citizens of the county. Since the new county government will be free to determine its own level of services (within the constraints of state law), the principal effect will be to increase the geographical scope of municipal government. Thus, bankruptcy-as-dissolution could lead to a merger of city and county, usually meaning city and suburbs-the objective of many a municipal reformer. ${ }^{242}$ Should the county government become insolvent, the state would provide the essential functions of government (since the county, unlike the city, is legally a subordinate unit of the state, performing the duties of the state, and not an agency of the local citizens).

244 The North Chicago school district recently voted to dissolve. Students would shift over to adjoining school districts, a move opposed by those districts. See Stanley Holmes and James Hill, New dilemma for schools: Who helps failed districts?, Chi Trib A1 (Mar 25, 1993).

245 Green, LA Times A12 (Jun 24, 1989) (cited in note 206).

${ }^{218}$ We recognize that the relations between cities and counties have changed significantly from the traditional model, and thus that in many states there would be practical problems with this result. We present it, however, as a thought experiment rather than a concrete proposal for reform.

${ }^{247}$ See, for example, Michael N. Danielson, The Politics of Exclusion 15-22 (Columbia, 1976); Frank S. Sengstock, Annexation: A Solution to the Metropolitan Area Problem (U Michigan Law School, 1960) (published in the series Legal Research Center, U Michigan Law School: Legal Problems in Metropolitan Areas); Symposium, Restructuring Metropolitan Area Government, 58 Georgetown L J 663 (1970); Note, The Urban County: a Study of New Approaches to Local Government in Metropolitan Areas, 73 Harv L Rev 526 (1960). 
This does not necessarily mean that the county would remain the sole municipal government. The merits of city dissolution must be understood in the context of the dynamic that arises when the provision of essential services devolves on the default general municipalities-the state and its local agents, the counties-which in turn will trigger a reconfiguring of public services in the affected area. The county and the state have an incentive to find some viable form of municipal corporation that will again absorb the costs of city government in the former city. Only if countywide government is more efficient will no new municipal corporation be created. Consider a hypothetical Bridgeport, located within a larger county. If Bridgeport actually becomes insolvent and dissolves, it would cease to exist and the essential service obligations would devolve upon the county and, ultimately, upon the state. If the citizens of the state became responsible for providing essential services to Bridgeport, the state would have the incentive to devise a more efficient new municipal structure to replace the old, the most likely outcome being some form of metropolitan government.

But if this is the proper disposition of the powers and obligations of the dissolved city, what is to become of its assets and its debts? As noted above, the state-and by the same logic the county-has not been deemed liable for the municipality's debts. If this rule were changed, states would presumably begin to exercise far more rigorous scrutiny of municipal financial affairs, a result that presumably would enhance fiscal responsibility but at the same time cut seriously into local autonomy. Determining the greater evil is a deeply political judgment, but we understand the movement in this century toward expanded home rule powers to be a collective judgment that local autonomy is worth some risk, and on that basis we assume that states and counties will not be forced to shoulder the debts of the bankrupt city.

We believe that assets should follow obligations. If the obligations of the city are inherited by the state or county, the assets should be inherited as well (subject to the same public trust that limited the city's ability to sell genuine "public trust" property). But if the obligations are discharged, non-public trust property should be sold for the payment of the debt. To the extent that some of the property has its highest and best use as governmental property, the county or the state can buy it. But for the same reason we believe that the common law doctrine against foreclosure on all public property is misguided, the citizens of the city should not be allowed to discharge their past debts while holding on to their accumulated assets. 


\section{Formation of New Cities}

What if we envision cities not as creatures of the state and part of a hierarchy of governments but as creations of their citizens, for pursuit of their own purposes? It follows, under such a view, that when any particular municipal corporation is dissolved, its non-public trust property will be sold and its people returned to the unincorporated mass from which they came. The people would then have the same right as any other groups of people living in unincorporated territory to form cities of their own liking. In short, the city becomes a voluntary association again, just as it was in the beginning. Indeed, at this stage, cities are hard to distinguish from homeowner associations or other voluntary associations of property owners-the sole important difference being that cities can form with less than unanimous consent. ${ }^{248}$

We assume that any new cities so created would, as a practical matter, have to satisfy state law definitions of a city, including-most importantly - the requirement of geographical contiguity. ${ }^{249}$ But there is nothing inherent in these definitions, and for heuristic purposes it is useful to abstract from the contiguity requirement, so as to expose the implications of the idea of the city as a contractual creation in its most radical form. Imagine contractual cities bound together by agreements of their inhabitants rather than the caprice of physical proximity-municipal archipelagoes. This enables us to dispense (in theory) with the need for less than unanimous consent, for these municipal archipelagoes need not include any unwilling citizens within their borders. There is nothing to prevent different configurations of municipal corporations for the provision of different services. Indeed (to return to the real world for a moment) the proliferation of special districts spanning more than one traditional jurisdiction is precisely this. The archipelago cities, we assume, can achieve necessary economies of scale through contractual arrangements among cities and private service-providers ${ }^{250}$-and for this thought experiment to work it is necessary to assume that any problems of negative externalities can be handled by higher units of government.

248 See Ellickson, $130 \mathrm{U} \mathrm{Pa} \mathrm{L}$ Rev at 1520 (cited in note 18); Advisory Comm'n on Intergovernmental Relations, Residential Community Associations: Private Governments in the Intergovernmental System? 1-7 (ACIR, May, 1989).

${ }^{240}$ See Ocean Beach Heights, Inc. v Brown-Crummer Investment Co., 302 US 614, 61820 (1938).

${ }_{250}$ See Gordon Tullock, Federalism: Problems of Scale, 6 Pub Choice 19, 21 (1969). 
The question we pose is whether contractual cities would be in the public interest. The answer requires a theory of the city and of its proper purposes. One purpose of cities is to provide public goods-any good for which it is impossible to exclude others from consuming and for which consumption by one person does not degrade consumption by another. National defense is the quintessential public good. ${ }^{251}$ Such goods would not be provided, or at least not in sufficient quantities, if left to private initiative. Moreover, there is a second class of goods, dubbed by economists "club goods," ${ }^{252}$ which have the characteristic that many persons can consume them simultaneously but after a certain point, there are negative externalities associated with additional consumers. ${ }^{253}$ Consider a public park on the Fourth of July. The second person to appear at the park is not barred from using the park because someone else was there first. This is true of the third person, and the fourth, etc. Nonetheless, at some point, each additional person further congests the park, and from the perspective of those already at the park, the new arrival imposes an additional cost on them and thereby decreases their enjoyment.

Many of the services associated with local government fall into this category. Municipal facilities and services such as parks, pools, forest preserves, museums, lakeside areas and police and fire protection can be considered club goods. These goods often will be natural monopolies, because they involve substantial fixed costs and low marginal costs for most (but not all) of the relevant range of production. The municipal swimming pool may be uncomfortably crowded on six afternoons during the year, but that does not mean it would pay to build a second pool. Public ownership is one

${ }^{251}$ Though there are doubts about whether even defense qualifies. See Richard Cornes and Todd Sandler, The Theory of Externalities, Public Goods and Club Goods 4 (Cambridge, 1986).

${ }_{282}$ This literature originated in James M. Buchanan, An Economic Theory of Clubs, 32 Economica 1 (1965). A general introduction to club goods can be found in Cornes and Sandler, Theory of Externalities at 1-25, 157-243 (cited in note 251); David A. Starrett, Foundations of Public Economics 40-62 (Cambridge, 1988). See also Eytan Sheshinski, The Supply of Communal Goods and Revenue Sharing, in Martin S. Feldstein and Robert P. Inman, eds, The Economics of Public Services 253 (International Economic Association, 1977); David E. Mills, Ownership Arrangements and Congestion-Prone Facilities, 71 Amer Econ Rev 493 (1981).

${ }^{253}$ In some sense, club goods are the flipside of goods exhibiting network externalities. For those goods, adding an additional consumer to the network increases the return to the preexisting consumer base. See Joseph Farrell and Garth Saloner, Standardization, Compatability, and Innovation, 16 Rand J Econ 70 (1985); Michael L. Katz and Carl Shapiro, Network Externalities, Competition, and Compatibility, 75 Amer Econ Rev 424 (1985). 
way to overcome the natural monopoly problem if regulation would be too cumbersome, or if it is difficult to exclude non-payers. ${ }^{284}$

The central idea of the club is that the owners of the means of production and the consumers of the production are identical. The producers therefore "internalize" precisely the preferences of the consumers. For private goods, there is almost always separation between consumption and ownership of the means of production. In competitive markets, this is irrelevant, as competitive forces effectively equate private profit maximization by producers with internalization by producers of consumer preferences. ${ }^{255}$ In contrast, in monopolistic or oligopolistic markets, the separation of ownership and consumption becomes a problem. Producers will internalize consumer preferences only partially. For example, a monopolist might very well engage in two-part pricing or might offer a complex peak-load pricing schedule to adjust for congestion effects. Nonetheless, a moncpolist constrained to offering the same schedule to each consumer, regardless of how complex that schedule is, will ultimately set prices in such a way that ignores the fact that some consumers are excluded from the good even if their value for it exceeds the marginal cost of producing it. In contrast, if the identical means of production were owned by the consumers-owned by a club-production decisions would more perfectly reflect consumer desire. ${ }^{256}$

The idea is that public ownership results in a closer tracking of consumer desire than would ownership by a private monopolist. This puts the city in the business of providing local public and club goods. Nonetheless, the full extent to which it can do so is far from unlimited and depends on a number of factors. As Charles Tiebout emphasized in his foundational work, ${ }^{257}$ individuals can move from place to place. The fact that a citizen can vote with his feet limits the extent to which disaffected citizens can be forced to share services with others. Furthermore, citizens in a given location may substitute private for public services. These two facts substan-

${ }^{254}$ Club goods also include private goods-meaning goods consumed by only one person or household-which have decreasing average costs over the relevant region. These too are local natural monopolies, and the same benefits of lining up producer interests and consumer interests may be obtained through club-or in this case, public-ownership.

${ }^{253}$ See Cornes and Sandler, Theory of Externalities at 188 (cited in note 251).

${ }^{258}$ The constraint to a single price schedule may matter. It is quite possible to imagine that a club would have an anti-price discrimination norm-everyone pays the same price for the same access-while a monopolist's only "norm" is maximizing profits, which would permit price disrimination if it was implementable at an acceptable price.

${ }^{257}$ Charles M. Tiebout, A Pure Theory of Local Expenditures, $64 \mathrm{~J}$ Polit Econ 416 (1956). 
tially circumscribe the manner in which a given city may provide goods and services.

As a rule, the gains from municipalization will be greater in communities that are relatively more homogeneous with respect to taste and effective demand, ${ }^{258}$ because the implicit cross-subsidies will be less. The presence of cross-subsidies substantially complicates what is achievable through public provision. Those subsidizing will seek to exit or will seek to substitute private services for public services. Moreover, if tastes, levels of demand, and ability to pay are all more or less constant in the area, then all the citizens will be more likely to gain from municipal provision of these goods than if the demands are widely disparate. One city may provide superior schools and playgrounds, another good golf courses and ordinances against noise; yet others will provide minimal services and low taxes. The variety of options makes everyone better off. This suggests that there is a sound economic basis for the proliferation of municipal corporations in modern metropolitan areas, where citizens of like tastes, interests, and income levels band together for the maximum mutual gains from public provision of public and club goods. It also suggests that one potential problem with the present organization of some cities is that they are too large and heterogeneous. ${ }^{259}$ Dissolving the municipal corporation could solve this. With prior boundaries dissolved, the citizens of the area would be free to consider and adopt alternative municipal arrangements.

The gains from this approach must be balanced against a number of competing factors. There are two nearly insuperable-but illuminating-difficulties with contractual cities.

First, bankruptcy as dissolution enables parts of the city to renege on implicit deals involving intra-municipal resource allocation. Some parts of the city will have received above-normal benefits in the form of public investment, on the implicit understanding that the city as a whole will benefit from the increased tax base. Now, after bankruptcy, those areas will have an incentive to divorce from the rest of the city, taking some of those benefits with them. ${ }^{260}$ From an ex ante perspective, allowing such opportunistic

${ }^{25 s}$ Of course, we are not speaking of homogeneity with respect to irrelevant or invidious characteristics, such as race or gender.

258 See note 258.

${ }^{200}$ Even if the benefits consist of municipal property that the new city must purchase, they will be better off than others of their former fellow citizens, who may have no such attractive purchase opportunities. 
behavior may inhibit cities from making efficient investments in particular parts of town. That will depend, of course, on how cities respond to the new bankruptcy rules. In theory, exit fees could be specified at the beginning, so those who seek to exit know what fees they have to pay. These might minimize the investment problems that might otherwise arise under the new bankruptcy rules, but they would not be easy to design or implement. ${ }^{261}$

Second, in a voluntary reconfiguration, parcels that have a high value relative to the costs of municipal services to them will be able to "bid" for a low tax rate from a compliant jurisdiction. The effect will be that few, if any, properties will be net income producers for the city. By the same token, parcels that have high costs of municipal services in relation to their value will be unwelcome fellow citizens: they will be excluded from the club. In short, this vision of municipal bankruptcy will bring an end to intra-municipal redistribution beyond the provision of essential services by the county.

This is surely an insuperable political objection (and may even be problematic for efficiency reasons as well). But theoretically, it should be possible to achieve the efficiency benefits without losing the optimal level of redistribution. A powerful argument can be made that redistribution, to the extent it is desirable, should be done at the largest jurisdictional level, namely the national government. ${ }^{262}$ To vest responsibility for redistribution in the cities would lead to both distorted decisions about location and insufficiently high levels of redistribution, since high redistribution rates will attract poor people and high tax rates will repel the wealthy. The other side of this coin, however, is that the charitable impulse seems to be stronger with respect to neighbors than to persons who live in distant places; that the noncharitable benefits of redistribution (esthetics, avoidance of moral or psychological discomfort, reduction in crime, if any) will accrue to the local level; and that local administration could be less bureaucratic and better tailored

${ }^{201}$ At least as applied after the fact to private individuals or businesses, exit fees are notoriously subject to abuse, and may well be unconstitutional. See Richard A. Epstein, Exit Rights Under Federalism, 55 L \& Contemp Probs 147, 155-65 (1992). But see In the Matter of the "Plan for Orderly Withdrawal from New Jersey" of Twin City Fire Insurance Company, 129 NJ 389, 609 A2d 1248 (1992), cert denied, 113 S Ct 1066 (1993) (upholding insurance industry exit testrictions against a variety of constitutional attacks).

${ }_{202}$ National redistribution would not be equivalent to national provision of local services. There is no necessary relationship between redistribution and public provision of services, though there may be a relationship between redistribution and public financing of such services. For many services, vouchers would be the most efficient form of subsidy. 
to individual needs. Whatever the balance of these considerations, the remedy of municipal dissolution followed by voluntary reconfiguration of boundaries would greatly reduce, if not eliminate, direct, local redistribution. If the purpose of cities is to create a more efficient means of providing public and club goods, this remedy will be superior. That it is politically impossible suggests that redistribution lies at the heart of the genuine purpose of the modern city. ${ }^{263}$

Assuming, however, that contract cities could coexist with redistributive goals, we can focus cleanly on the efficiency issues. The reason for introducing public ownership or control of local monopolies was that the monopolist would ignore the effects of excluding some consumers from its goods. The same concerns can be raised about our contract cities: will these cities exclude some who should be admitted? The answer is almost certainly yes. For fixed facilities with equal access to them, an existing group of citizens will admit another consumer only if the per-citizen decrease in taxes exceeds the per-citizen increase in congestion costs from the additional consumer. This plainly differs from the social calculation, which asks whether the advantages to membership/citizenship for the outsider exceed the additional congestion costs. The payment by the outsider is just a transfer and has no efficiency effects. As always, there is no necessary relationship between ability to pay and benefits received from the good sought to be purchased. It is quite plausible that the advantages from membership for the outsider far exceed the marginal congestion costs, yet the outsider will lack the wherewithal to compensate the existing members for those costs. Note that it is not the transaction costs of compensating the preexisting citizens that drives this-the city itself is a collective (and collecting) device-but rather it is the gap between the outsider's resources and benefits received.

For fixed facilities, then, we have a reason to favor mandatory access-meaning admission to citizenship in this context-and disfavoring the purely volitional contract cities suggested above. The critical question is the extent to which forcing admission will alter the given fixed facilities themselves. We have argued that evenhanded distribution of city goods and services under a non-contractual city regime results in cross-subsidization. The requirement of contiguity-the basic definitional instrument for non-contractual cities-coupled with even-handed distribution of resources

${ }^{26 s}$ As Ellickson concludes. See Ellickson, $130 \mathrm{U} \mathrm{Pa}$ L Rev at 1520 (cited in note 18). 
within the city, almost surely causes one group to subsidize the other. Individuals may be able to substitute, albeit imperfectly, between public and private services. Indeed, the rise of private police forces and security services, is almost surely an effort by able-topay taxpayers to capture more of the benefits associated with what otherwise would have been generally available protections services, i.e. traditional police officers. More generally, individuals forced to share with others may find it in their private interest to drop the level of general public services and to instead substitute private services.

A number of empirical questions must be confronted. What are the precise efficiency effects of subtituting private for public services? If you install "The Club"-a popular anti-theft device for automobiles-on your car, you divert the thief from your car to my car. If I now hire a person to guard my car, I may redirect the thief's attention. If we each spend enough, perhaps the thief leaves the car theft business entirely, but it is far from obvious our private choices are the best way to reach this goal. On the other side, what are the gains from allowing city outsiders access to the city's shared resources? The gains to an inner city child from access to a wealthy suburban education might far exceed the marginal congestion costs to the existing students.

These are empirical questions. The great virtue of contiguity as a defining device is that it now costs almost nothing to implement. Our contract cities would result in large market transaction costs. The prospect of each US citizen entering the city market, armed with private funds and public vouchers, is daunting. The information, negotiation, and other transaction costs might very well dwarf any of the benefits to be obtained through allowing free contracting. This is especially so with free movement between cities, as citizens can sort and achieve homogeneity by moving from one jurisdiction to another. If we are right in our assessment of the likely costs of free contracting to form cities, this suggests that accepting the existing borders of the failed city may be the right outcome after all. This is not because the city cannot be liquidated-it can-but rather that the benefits of free contracting are likely to be few relative to the substantial costs of disturbing the status quo.

We have pursued the notion of contract cities to see whether it is possible to achieve greater efficiency in the provision of public services. We have argued that the inability to exclude fellow citizens from the benefits of public services may lead to underprovision of public services. Contract cities could achieve greater homo- 
geneity of taste and demand for services, and that may be necessary to create optimal public provision. On the one hand, greater homogeneity may result in less substitution of inefficient private services for public services; on the other hand, more jurisdictions means more borders-and this is especially true of our municipal archipelagos-and borders give rise to all sorts of externalities.

\section{Conclusion}

It seems elementary to say that when cities go broke it is probably a sign of fundamental trouble. But federal municipal bankruptcy law is premised on the notion that all the cities need is relief from their present creditors. In keeping with the extremely limited common law remedies for municipal nonpayment of debt, Chapter 9 leaves control in the hands of the state and the muncipality itself. The structure for making decisions that led to financial problems continues. The bankruptcy court lacks the powers typically given to state municipal receivers to deal with such issues as wasteful expenditures, bloated services or contracts, inadequate tax systems, or inefficient boundaries. The effect is all relief of symptoms, at best-no bitter medicine and no cure. Municipal bankruptcy thus lacks any of the internal disciplines of private bankruptcy. In their place, Chapter 9 imposes a series of filing restrictions-state authorization, insolvency, best interests of the creditors, and good faith-so stringent that few significant municipalities have been able to make use of it.

We have suggested that a more powerful bankruptcy court, grounded in state rather than federal law, would better serve the purposes of bankruptcy and improve the lot of financially troubled cities. More speculatively, we have suggested that the more radical step of dissolution of the city deserves serious consideration. Dissolution would lead to either metropolitanization of the city government (thus improving the tax base) or to new cities created by the citizens. The latter idea would facilitate the provision of public and club goods, but would create new border problems.

Even if these proposals prove unworkable, we believe that federal bankruptcy law warrants serious reexamination. In its present form, it serves little use: it does little to address serious city problems and, by restricting state laws directed at solving the holdout problem, even impedes the ability of states to institute superior schemes for dealing with cities that have gone broke. It is ironic that a statute that has it roots in providing a way to solve the holdout problem does little more than prevent the states from 
doing so themselves. In law, as in medicine, the first rule is to do no harm. By frustrating state initiatives and providing an inaccessible and weak alternative, federal municipal bankruptcy law fails that test. 
HeinOnline -- 60 U. Chi. L. Rev. 4961993 